Electronic Supplementary Information for:

\title{
Synthesis of Carboxy ATTO 647N Using Redox Cycling for Xanthone Access
}

James L. Bachman,${ }^{\dagger}$ Cyprian I. Pavlich,${ }^{\dagger}$ Alexander J. Boley, ${ }^{\dagger}$ Edward M. Marcotte, ${ }^{\dagger}$ and Eric V. Anslyn ${ }^{\dagger *}$

†Department of Chemistry, The University of Texas at Austin, Austin, TX 78712, USA.

†Department of Molecular Biosciences, The University of Texas at Austin, Austin, TX 78712, USA

*anslyn@austin.utexas.edu

\section{Contents:}

Experimental section...S2-S8

${ }^{1} \mathrm{H}$ and ${ }^{13} \mathrm{C}$ NMR Spectral Data...S9-S32

Mass Spectral Data...S33-S43

References...S44 


\section{EXPERIMENTAL METHODS}

General Considerations: Reactions were performed in the piece of glassware specified in each protocol. Purification by flash chromatography was performed with $60 \AA$ silica gel purchased from Sorbent Technologies, Inc. HPLC purification was performed on a Shimadzu Prominence HPLC equipped with a Zorbax SB-C 18 preparatory column $(21.2 \times 250 \mathrm{~mm})$ with $7.0 \mu \mathrm{m}$ packing material. Any reaction run in anhydrous conditions was performed in glassware that was flamedried under vacuum prior to reaction. The ${ }^{1} \mathrm{H}$ NMR and ${ }^{13} \mathrm{C}$ NMR spectra were recorded on a Bruker AVANCE III 500 NMR, supported by NSF grant 1 S10 OD021508-01. Chemical shifts are reported in parts per million $(\delta)$ referenced internally to the residual solvent peak. Deuterated NMR solvents were obtained from Cambridge Isotope Laboratories and used as received. LCMS spectra were recorded on an Agilent Technologies 6130 single quadrupole LCMS using electrospray ionization. Reactions were monitored at $280 \mathrm{~nm}$. High resolution mass spectra were recorded on an Agilent Technologies 6530 Accurate Mass Q-TOF using electrospray ionization. Infrared spectra were recorded on a Perkin-Elmer 1600 spectrometer using a diamond ATR unit.

Materials: The following solvents were purchased from commercial sources and used without further purification: methanol Certified ACS (Fisher Scientific), ethanol absolute (Fisher Scientific), 1,2-dichloroethane $(99.8 \%+)$ (Fisher Scientific), 1-methyl-2-pyrrolidinone (Fisher Scientific), 37\% hydrogen chloride solution (Fisher Scientific), benzyl alcohol (99\%) (Fisher Scientific), chlorobenzene $\left(99 \%^{+}\right)$(Acros Organics), acetic anhydride certified ACS (Fischer), $N, N$-dimethylformamide Certified ACS (Fischer Scientific). Toluene Certified ACS was distilled over $\mathrm{P}_{2} \mathrm{O}_{5}$ dried with $4 \AA$ mol sieves (Fischer Scientific). The following solvents were treated with a Vacuum Atmospheres Company Solvent Purification System (SPS) for drying and then stored on activated $4 \AA$ mol sieves: tetrahydrofuran stab. 0.025\% BHT (Fischer Scientific), dichloromethane (99.9\%) (Fischer Scientific), and $N, N$-dimethylformamide certified ACS (Fischer Scientific). Acetone certified ACS (Fischer Scientific) was dried with $\mathrm{K}_{2} \mathrm{CO}_{3}$ overnight and filtered prior to use. The following compounds were purchased from commercial sources and used without purification unless indicated: 3-bromoaniline 98\% (Millipore Sigma), mesityl oxide 98\% (Millipore Sigma), boron trifluoride etherate, ca. 48\% BF 3 (Acros Organics), epichlorohydrin 99\% (Acros Organics), n-butyllithium solution 2.5 M in hexanes (Millipore Sigma), $t$-butyllithium solution $1.7 \mathrm{M}$ in hexanes (Millipore Sigma), boron trichloride solution $1.0 \mathrm{M}$ in methylene chloride (Millipore Sigma), 10\% wt. Pd/C (Millipore Sigma), $\mathrm{KHSO}_{4}$ puriss. (Millipore Sigma), $\mathrm{H}_{3} \mathrm{PO}_{4} 85 \%$ wt. in $\mathrm{H}_{2} \mathrm{O}$ (Millipore Sigma), phosphorus pentoxide ( $\geq 98.5 \%$ ) (Millipore Sigma), iodine (Millipore Sigma), $\mathrm{Na}_{3} \mathrm{PO}_{4}$ tribasic dodecahydrate $\geq 98 \%$ (Millipore Sigma), 2bromobenzoic acid 97\% (Aldrich), thionyl chloride (99.5\%+) (Acros organics), 2-amino-2methylpropan-1-ol (Spectrum Products), juololidine 98\% (Alfa Aesar), 4-(Methylamino)butyric acid hydrochloride $99 \%$ (Millipore Sigma), fluoro-dipyrrolidinocarbenium hexafluorophosphate $\geq 99 \%$ (Millipore Sigma), N,N-diisopropylethylamine dried over $\mathrm{NaOH}$ (Millipore Sigma), phosphorous (V) 99.999\% (Acros Organics), $N, N, N^{\prime}, N^{\prime}$-tetramethylethylenediamine $\geq 99.5 \%$, sodium borohydride $\geq 98 \%$ (Millipore Sigma), di-tert-butyl dicarbonate reagentPlus $\geq 99 \%$ (Millipore Sigma), 4-(methylamino)butyric acid hydrochloride 99\% (Millipore Sigma). 


\section{2,3,6,7-tetrahydro-1H,5H-pyrido[3,2,1-ij] quinoline-9-carbaldehyde (16):}

To a $100 \mathrm{~mL}$ round-bottomed flask under an argon atmosphere, $N, N$-dimethylformamide $(21 \mathrm{~mL})$ was added by syringe, which was cooled to $0{ }^{\circ} \mathrm{C}$ with an external ice bath. $\mathrm{POCl}_{3}(4.7 \mathrm{~mL}, 50.3$ mmol) was added dropwise by syringe and then stirred for 30 minutes at this temperature. To the reaction mixture, a solution of julolidine $15(7.0 \mathrm{~g}, 40.5 \mathrm{mmol})$ in $N, N$-dimethylformamide (10 $\mathrm{mL}$ ) was added dropwise by syringe. Following addition, the reaction was allowed to warm to room temperature and then placed in a pre-heated oil bath at $90{ }^{\circ} \mathrm{C}$ and stirred for 1.5 hours. Upon cooling to room temperature, the reaction was added to a $1 \mathrm{~L}$ Erlenmeyer flask with water $(400$ $\mathrm{mL}$ ). Solid $\mathrm{KOH}$ pellets were added until the solution was $\sim \mathrm{pH} 12-13$. The solution was extracted with EtOAc $(4 \times 50 \mathrm{~mL})$ and the organic extracts were combined and dried over $\mathrm{Na}_{2} \mathrm{SO}_{4}$. Following filtration, the solution was concentrated by rotary evaporation and the green solid was triterated with hexanes and decanted until no color was produced, giving $16(6.5 \mathrm{~g}, 32.3 \mathrm{mmol})$ as a green-brown solid in $80 \%$ yield, which was used without further purification. This compound is known. ${ }^{1}{ }^{1} \mathrm{H}-\mathrm{NMR}\left(500 \mathrm{MHz}, \mathrm{CDCl}_{3}\right) \delta$ : $9.58(\mathrm{~s}, 1 \mathrm{H}), 7.27(\mathrm{~s}, 2 \mathrm{H}), 3.27$ (t, $\left.J=5.8 \mathrm{~Hz}, 4 \mathrm{H}\right), 2.75$ (t, $J=6.3 \mathrm{~Hz}, 4 \mathrm{H}), 1.95$ (p, $J=6.1 \mathrm{~Hz}, 4 \mathrm{H}) .{ }^{13} \mathrm{C}-\mathrm{NMR}\left(126 \mathrm{MHz}, \mathrm{CDCl}_{3}\right) \delta: 90.1,147.9,129.4$, $124.0,120.3,50.0,27.7,21.3$.

\section{(2,3,6,7-tetrahydro-1H,5H-pyrido[3,2,1-ij]quinolin-9-yl)methanol (10):}

Compound $16(1.2 \mathrm{~g}, 5.97 \mathrm{mmol})$ was charged to a $100 \mathrm{~mL}$ round-bottomed flask equipped with a magnetic stirbar. Ethanol $(25 \mathrm{~mL})$ was added by graduate cylinder. $\mathrm{NaBH}_{4}(350 \mathrm{mg}, 9.2 \mathrm{mmol})$ was added in five portions at room temperature over the course of 30 minutes and the reaction was stirred for 1 hour following addition. The reaction was quenched by the addition of water $(25 \mathrm{~mL})$. The aqueous layer was extracted with EtOAc $(3 \times 25 \mathrm{~mL})$ and the organic layers were combined and dried over $\mathrm{MgSO}_{4}$, filtered and concentrated. The reaction was purified with silica gel flash chromatography (hexanes to 4:1 hexanes/EtOAc) giving 10 (938 mg, $4.6 \mathrm{mmol}$ ) in $77 \%$ yield as either a white solid if concentrated from hexanes/EtOAc or as a red oil if concentrated from methylene chloride. The primary alcohol oxidizes readily and thus was used immediately upon isolation. Note: the alcohol degraded rapidly in $\mathrm{CHCl}_{3}$ on the time scale of ${ }^{13} \mathrm{C} \mathrm{NMR}$ analysis and thus the reported spectra are taken in different solvents. ${ }^{1} \mathrm{H}-\mathrm{NMR}\left(500 \mathrm{MHz}, \mathrm{CDCl}_{3}\right) \delta: 6.80(\mathrm{~s}$, 2H), 4.47 (s, 2H), $3.13(\mathrm{t}, J=5.6 \mathrm{~Hz}, 4 \mathrm{H}), 2.75(\mathrm{t}, J=6.4 \mathrm{~Hz}, 4 \mathrm{H}), 1.94-2.0(\mathrm{~m}, 4 \mathrm{H}), 1.42(\mathrm{~s}, 1 \mathrm{H})$. ${ }^{13} \mathrm{C}-\mathrm{NMR}\left(126 \mathrm{MHz}, \mathrm{CD}_{3} \mathrm{OD}\right) \delta$ : 142.2, 128.5, 126.1, 121.5, 64.1, 49.9, 27.3, 22.0. HRMS (ESI) $m / z:(\mathrm{M}+1 \mathrm{H})^{+}$Calcd for $\mathrm{C}_{13} \mathrm{H}_{18} \mathrm{NO} 204.1383$; found 204.1387.

7-bromo-2,2,4-trimethyl-1,2-dihydroquinoline (17): To a flame-dried $100 \mathrm{~mL}$ round-bottomed flask equipped with a magnetic stir bar was added 3-bromoaniline $(\mathbf{1 4})(6.31 \mathrm{~mL}, 58.0 \mathrm{mmol})$ and mesityl oxide (13) (13.269 mL, $116 \mathrm{mmol})$ both via syringe. Iodine $(1.2 \mathrm{~g}, 4.7 \mathrm{mmol})$ was charged to the RBF and the flask placed under a flow of $\mathrm{N}_{2}$. Anhydrous toluene $(30 \mathrm{~mL})$ was added via syringe. The reaction was placed in a pre-heated oil bath at $110{ }^{\circ} \mathrm{C}$ and stirred for 18 hours. After cooling to room temperature, the reaction was concentrated by rotary evaporation. The crude solid was dissolved in methylene chloride and pre-adsorbed to silica gel. This was purified by silica gel flash chromatography with neat hexanes to $50: 1$ hexanes/EtOAc, providing $17(7.89 \mathrm{~g}, 31.3 \mathrm{mmol})$ as a yellow oil, which precipitated into a yellow-brown solid in a $54 \%$ yield. This compound is known. ${ }^{2}{ }^{1} \mathrm{H}-\mathrm{NMR}\left(500 \mathrm{MHz}, \mathrm{CDCl}_{3}\right) \delta: 6.88(\mathrm{~d}, J=8.1 \mathrm{~Hz}, 1 \mathrm{H}), 6.73(\mathrm{~d}, J=8.1 \mathrm{~Hz}, 1 \mathrm{H}), 6.56$ $(\mathrm{s}, 1 \mathrm{H}), 5.31(\mathrm{~s}, 1 \mathrm{H}), 1.95(\mathrm{~s}, 3 \mathrm{H}), 1.27(\mathrm{~s}, 6 \mathrm{H}) .{ }^{13} \mathrm{C}-\mathrm{NMR}\left(126 \mathrm{MHz}, \mathrm{CDCl}_{3}\right) \delta: 144.3,128.6$, $127.9,121.7,120.5,119.9,115.4,52.2,31.8,18.5$. 

(triethyloxonium tetrafluoroborate) $^{3}$ was generated by the careful addition of boron trifluoride etherate $(4.62 \mathrm{~mL}, 37.4 \mathrm{mmol})$ to a stirred solution of epichlorohydrin $(2.48 \mathrm{~mL}, 30.7 \mathrm{mmol})$ in anhydrous diethyl ether $(100 \mathrm{~mL})$ under argon in a flame-dried $250 \mathrm{~mL}$ round-bottomed flask. The solution was then heated at refluxed for two hours. The solid Meerwein's salt precipitated out of solution, the ether was decanted and the reaction dried under high-vacuum for 30 minutes to afford a fluffy white solid. The RBF was placed under a flow of $\mathrm{N}_{2}$ and 1,2-dichloroethane $(50 \mathrm{~mL})$ was added via syringe, with $17(7.01 \mathrm{~g}, 27.8 \mathrm{mmol})$ charged to the round-bottomed flask, which was then placed in a pre-heated oil bath at $80^{\circ} \mathrm{C}$ and stirred for 18 hours. After cooling to room temperature, the solvent was removed by rotary evaporation. The crude solid was dissolved in methylene chloride and pre-adsorbed to silica gel. The compound was purified by silica gel flash chromatography with neat hexanes to 100:1 hexanes/EtOAc, providing $12(5.59 \mathrm{~g}, 20.0 \mathrm{mmol})$ as a yellow oil in $71 \%$ yield. ${ }^{1} \mathrm{H}-\mathrm{NMR}\left(500 \mathrm{MHz}, \mathrm{CDCl}_{3}\right) \delta: 6.86(\mathrm{~d}, J=8.2 \mathrm{~Hz}, 1 \mathrm{H}), 6.69(\mathrm{~d}, J=$ $8.1 \mathrm{~Hz}, 1 \mathrm{H}), 6.58(\mathrm{~s}, 1 \mathrm{H}), 5.21(\mathrm{~s}, 1 \mathrm{H}), 3.20(\mathrm{q}, J=7.1 \mathrm{~Hz}, 2 \mathrm{H}), 1.94(\mathrm{~s}, 3 \mathrm{H}), 1.32(\mathrm{~s}, 6 \mathrm{H}), 1.20(\mathrm{t}$, $J=7.0 \mathrm{~Hz}, 3 \mathrm{H}) .{ }^{13} \mathrm{C}-\mathrm{NMR}\left(126 \mathrm{MHz}, \mathrm{CDCl}_{3}\right) \delta 144.8,129.4,127.1,124.9,122.6,121.4,117.8$, 112.8, 57.1, 38.1, 28.8, 18.6, 14.0. HRMS (ESI) $\mathrm{m} / \mathrm{z}:(\mathrm{M}+1 \mathrm{H})^{+}$for $\mathrm{C}_{14} \mathrm{H}_{19} \mathrm{NBr}$ calcd 280.0695; found 280.0700 .

\section{2-(1-ethyl-2,2,4-trimethyl-1,2-dihydroquinolin-7-yl)propan-2-ol (18):}

A solution of $12(4.0 \mathrm{~g}, 14.39 \mathrm{mmol})$ in anhydrous THF $(40 \mathrm{~mL})$ was prepared in a flame-dried $100 \mathrm{~mL}$ round-bottomed flask equipped with magnetic stirbar. This was placed in external dry ice/acetone bath, cooling it to $-78^{\circ} \mathrm{C} .2 .5 \mathrm{M} n$-BuLi solution in hexanes $(6.9 \mathrm{~mL}, 17.29 \mathrm{mmol})$ was slowly added and stirred for 30 minutes. A solution of anhydrous acetone $(6 \mathrm{~mL}, 80.99 \mathrm{mmol})$ cooled to $-78^{\circ} \mathrm{C}$ was added in two rapid additions via syringe and then stirred for a further $1 \mathrm{~h}$ at this temperature. The reaction was warmed to room temperature and then added to an ice-cold solution of $20 \% \mathrm{NH}_{4} \mathrm{Cl}(100 \mathrm{~mL})$. The aqueous mixture was extracted with EtOAc $(3 \times 50 \mathrm{~mL})$ and dried over $\mathrm{MgSO}_{4}$, which was filtered and the solvent removed by rotary evaporation. The crude product was purified by silicia gel flash chromatography with 9:1 hexanes/EtOAc, providing $18(3.05 \mathrm{~g}, 11.80 \mathrm{mmol})$ as a yellow oil in $82 \%$ yield. ${ }^{1} \mathrm{H}-\mathrm{NMR}\left(500 \mathrm{MHz}, \mathrm{CDCl}_{3}\right) \delta: 7.01(\mathrm{~d}, J=$ $8.0 \mathrm{~Hz}, 1 \mathrm{H}), 6.66(\mathrm{~d}, J=7.2 \mathrm{~Hz}, 2 \mathrm{H}), 5.18(\mathrm{~s}, 1 \mathrm{H}), 3.36$ (q, $J=7.0 \mathrm{~Hz}, 2 \mathrm{H}), 1.96$ (s, 3H), 1.58 (s, $6 \mathrm{H}), 1.22(\mathrm{t}, J=7.0 \mathrm{~Hz}, 3 \mathrm{H}) .{ }^{13} \mathrm{C}-\mathrm{NMR}\left(126 \mathrm{MHz}, \mathrm{CDCl}_{3}\right) \delta: 149.6,143.4,128.9,127.3,123.5$, $121.1,72.7,57.0,38.0,31.6,28.9,18.7,14.3$. HRMS (ESI) $m / z:(\mathrm{M}+1 \mathrm{H})^{+} \mathrm{C}_{17} \mathrm{H}_{26} \mathrm{NO}$ calcd 260.2009; found 260.2016 .

\section{2-(1-ethyl-2,2,4-trimethyl-1,2,3,4-tetrahydroquinolin-7-yl)propan-2-ol (19):}

To a $250-\mathrm{mL}$ round-bottomed flask equipped with magnetic stirbar, $18(2.0 \mathrm{~g}, 7.72 \mathrm{mmol})$ and $10 \%$ wt. $\mathrm{Pd} / \mathrm{C}(300 \mathrm{mg})$ were charged, with $\mathrm{EtOH}(100 \mathrm{~mL})$ added by graduated cylinder. The solution was sparged with 2 large balloons of nitrogen gas followed by 3 large balloons of hydrogen gas and then stirred for 18 hours under a hydrogen atmosphere at room temperature. The reaction mixture was filtered through a pad of celite and the solvent removed by rotary evaporation to give $19(1.91 \mathrm{~g}, 7.33 \mathrm{mmol})$ as a clear, redish oil in $95 \%$ yield without further purification. ${ }^{1} \mathrm{H}$ NMR $\left(400 \mathrm{MHz}, \mathrm{CDCl}_{3}\right) \delta: 7.11(\mathrm{~d}, J=7.8 \mathrm{~Hz}, 2 \mathrm{H}), 6.75(\mathrm{~s}, 1 \mathrm{H}), 6.70(\mathrm{~d}, J=7.9 \mathrm{~Hz}, 1 \mathrm{H}), 3.48$ $(\mathrm{dq}, J=14.2,7.0 \mathrm{~Hz}, 1 \mathrm{H}), 3.23(\mathrm{dq}, J=14.0,6.9 \mathrm{~Hz}, 1 \mathrm{H}) 2.85-2.90(\mathrm{~m}, 1 \mathrm{H}), 1.71(\mathrm{dd}, J=12.9$, $4.6 \mathrm{~Hz}, 2 \mathrm{H}), 1.59$ (s, 6H), 1.32 (d, $J=6.3 \mathrm{~Hz}, 6 \mathrm{H}), 1.22$ (t, $J=7.0 \mathrm{~Hz}, 3 \mathrm{H}), 1.19$ (s, 3H). ${ }^{13} \mathrm{C}-\mathrm{NMR}$ $\left(126 \mathrm{MHz}, \mathrm{CDCl}_{3}\right) \delta: 147.8,144.5,125.9,125.6,110.9,107.2,72.6,54.4,46.9,39.0,31.6,29.98$, 27.0, 25.2, 20.0, 15.8. HRMS (ESI) $m / z$ : $(\mathrm{M}+1 \mathrm{H})^{+}$for $\mathrm{C}_{17} \mathrm{H}_{28} \mathrm{NO}$ calcd 262.2165; found 262.2168. 
1-ethyl-2,2,4-trimethyl-7-(prop-1-en-2-yl)-1,2,3,4-tetrahydroquinoline (11):

To a 6-dram vial equipped with magnetic stibar and a teflon cap, 19 (1.5 g, $5.74 \mathrm{mmol})$ and $\mathrm{KHSO}_{4}$ (780 mg, $5.73 \mathrm{mmol}$ ) were charged, with anhydrous chlorobenzene $(8 \mathrm{~mL})$ added by syringe. The vial was sealed with teflon tape and the reaction mixture was placed in a pre-heated oil bath at $140{ }^{\circ} \mathrm{C}$ and stirred for 10 minutes. After cooling to room temperature, the reaction was poured in sat. $\mathrm{NaHCO}_{3}(20 \mathrm{~mL})$. The layers were separated and the aqeuous was was further extracted with EtOAc $(3 \times 15 \mathrm{~mL})$. The combined organic layers were dried over $\mathrm{Na}_{2} \mathrm{SO}_{4}$, filtered and the solvent removed under reduced pressure. The oil was purified by flushng through a plug of silica gel with 1:1 hexanes/EtOAc to give $11(1.17 \mathrm{~g}, 4.82 \mathrm{mmol})$ as a yellow oil in 84\% yield. ${ }^{1} \mathrm{H}-\mathrm{NMR}$ (500 $\left.\mathrm{MHz} \mathrm{CDCl}_{3}\right) \delta: 7.11(\mathrm{~d}, J=8.1 \mathrm{~Hz}, 1 \mathrm{H}), 6.74(\mathrm{~d}, J=8.1 \mathrm{~Hz}, 1 \mathrm{H}), 6.67(\mathrm{~s}, 1 \mathrm{H}), 5.30(\mathrm{~s}, 1 \mathrm{H}), 5.01$ $(\mathrm{s}, 1 \mathrm{H}), 3.43-3.51(\mathrm{~m}, 1 \mathrm{H}), 3.19-3.26(\mathrm{~m}, 1 \mathrm{H}), 2.86-2.93(\mathrm{~m}, 1 \mathrm{H}), 2.15(\mathrm{~s}, 3 \mathrm{H}), 1.72(\mathrm{dd}, J=13.2$ $\mathrm{Hz}, 4.9 \mathrm{~Hz}, 1 \mathrm{H}), 1.57$ (t, $J=12.9 \mathrm{~Hz}, 1 \mathrm{H}), 1.33(\mathrm{~d}, J=5.2 \mathrm{~Hz}, 6 \mathrm{H}), 1.23(\mathrm{t}, J=7.2 \mathrm{~Hz}, 3 \mathrm{H}), 1.18$ (s, 3H). ${ }^{13} \mathrm{C}-\mathrm{NMR}\left(126 \mathrm{MHz}, \mathrm{CDCl}_{3}\right) \delta 144.4,144.4,140.1,127.0,125.7,112.5,111.2,108.3$, 54.3, 47.0, 39.0, 29.8, 27.1, 25.1, 22.0, 20.0, 15.1. HRMS (ESI) $m / z$ : $(\mathrm{M}+1 \mathrm{H})^{+}$for $\mathrm{C}_{17} \mathrm{H}_{26} \mathrm{~N}$ calcd 244.2060; found 244.2065.

\section{Xanthone (6):}

To a stirred solution of $\mathbf{1 1}(1.3 \mathrm{~g}, 5.35 \mathrm{mmol})$ and alcohol $\mathbf{1 0}(1.06 \mathrm{~g}, 5.22 \mathrm{mmol})$ in anhydrous $\mathrm{CH}_{2} \mathrm{Cl}_{2}(20 \mathrm{~mL})$ prepared in a $50-\mathrm{mL}$ round-bottomed flask under argon cooled to $-78{ }^{\circ} \mathrm{C}, 1.0 \mathrm{M}$ $\mathrm{BCl}_{3}$ in $\mathrm{CH}_{2} \mathrm{Cl}_{2}(5.7 \mathrm{~mL}, 5.7 \mathrm{mmol})$ was added drop-wise by syringe and stirred overnight, allowing the reaction to slowly warm to room temperature. Separately, to a $100-\mathrm{mL}$ pear-shaped flask, a solution of $85 \%$ phosphoric acid $(3.2 \mathrm{~mL})$ was added to solid $\mathrm{P}_{2} \mathrm{O}_{5}(7.5 \mathrm{~g}, 53.2 \mathrm{mmol})$ and stirred at $120^{\circ} \mathrm{C}$ for 20 minutes, using a spatula to break up chunks of $\mathrm{P}_{2} \mathrm{O}_{5}$ to produced a viscous oil. After cooling to room temperature, the $\mathrm{CH}_{2} \mathrm{Cl}_{2}$ reaction mixture was added to the phosphoric acid and the $\mathrm{CH}_{2} \mathrm{Cl}_{2}$ was removed by heavy nitrogen flow. Once most solvent was removed, the resulting mixture was stirred at $115^{\circ} \mathrm{C}$ for 3 hours, which boiled off residual $\mathrm{CH}_{2} \mathrm{Cl}_{2}$. This reaction can "foam up" and produced a very viscous substance. Using a heat gun to warm the sides of the flask that are not in direct contact with the heal bath can help to keep the foam in solution. Once the reaction has settled, it will appeared as a dark orange viscous oil. Upon cooling to room temperature, ice and solid $\mathrm{KOH}$ were added until the $\mathrm{pH}$ was $\sim 12$, turning the orange melt into a dark blue solution. The aqueous solution was extracted with $\mathrm{CH}_{2} \mathrm{Cl}_{2}(3 \times 50 \mathrm{~mL})$, washed with brine $(1 \times 30 \mathrm{~mL})$ then dried over $\mathrm{Na}_{2} \mathrm{SO}_{4}$. Note: excess $\mathrm{CH}_{2} \mathrm{Cl}_{2}$ may be needed to rinse the glassware and get all of the oil into solution. Following filtration and solvent evaporation, the crude solid was transferred to a $100-\mathrm{mL}$ round-bottomed flask equipped with a magnetic stirbar. $N$ Methyl-2-pyrrolidinone (20 mL), $\mathrm{I}_{2}(1.32 \mathrm{~g}, 5.22 \mathrm{mmol}), \mathrm{Na}_{3} \mathrm{PO}_{4}(3.96 \mathrm{~g}, 10.4 \mathrm{mmol})$ and $\mathrm{H}_{2} \mathrm{O}$ $(0.5 \mathrm{~mL})$ were added and the reaction mixture which was capped with a rubber septum and secured with teflon tape. The solution was stirred at $23{ }^{\circ} \mathrm{C}$ for $5 \mathrm{~min}$ before being placed in a pre-heated oil bath at $115^{\circ} \mathrm{C}$ and stirred for 8 hours. At this time, some xanthene was observable by TLC, an additional spatula tip of both $\mathrm{I}_{2}$ and $\mathrm{Na}_{3} \mathrm{PO}_{4}$ were added and the solution and stirred at $75{ }^{\circ} \mathrm{C}$ overnight. After cooling to room temperature, the reaction was filtered through a pad of celite, which was washed with methylene chloride and methanol until colorless. The crude organic solution was concentrated by rotary evaporation with the remaining NMP removed by vacuum distillation $\left(50-65^{\circ} \mathrm{C}, 25 \mathrm{~mm} \mathrm{Hg}\right)$. The crude mixture was dissolved in sat. aqueous $\mathrm{NaHCO}_{3}(100$ $\mathrm{mL})$ and then extracted with $\mathrm{CH}_{2} \mathrm{Cl}_{2}(5 \times 100 \mathrm{~mL})$, the organic extracts were combined and dried over $\mathrm{Na}_{2} \mathrm{SO}_{4}$. Note: some emulsification occurred, this was broken up with additional $\mathrm{CH}_{2} \mathrm{Cl}_{2}$. The solution was filtered, concentrated, pre-adsorbed onto silica gel and purified with silica gel column 
chromatography (8:2 hexanes/ $\mathrm{CH}_{2} \mathrm{Cl}_{2}$ to $6: 2: 2$ hexanes $/ \mathrm{CH}_{2} \mathrm{Cl}_{2} / \mathrm{EtOAc}$ ) to give $\mathbf{6}$ as a bright yellow solid (921 mg, $2.08 \mathrm{mmol})$ in 40\% yield. ${ }^{1} \mathrm{H}-\mathrm{NMR}\left(500 \mathrm{MHz}, \mathrm{CDCl}_{3}\right) \delta: 8.07(\mathrm{~s}, 1 \mathrm{H}), 8.00$ $(\mathrm{s}, 1 \mathrm{H}), 6.56(\mathrm{~s}, 1 \mathrm{H}), 3.52-3.60(\mathrm{~m}, 1 \mathrm{H}), 3.33-3.38(\mathrm{~m}, 1 \mathrm{H}), 3.29(\mathrm{q}, J=6.3 \mathrm{~Hz}, 4 \mathrm{H}), 3.02-3.03(\mathrm{t}$, $J=5.8 \mathrm{~Hz}, 2 \mathrm{H}), 2.88-2.94(\mathrm{~m}, 1 \mathrm{H}), 2.82(\mathrm{t}, J=6.2 \mathrm{~Hz}, 3 \mathrm{H}), 1.97(\mathrm{~h}, J=6.8 \mathrm{~Hz}, 4 \mathrm{H}), 1.82(\mathrm{~s}$, $6 \mathrm{H}), 1.76(\mathrm{dd}, J=13.2 \mathrm{~Hz}, 4.3 \mathrm{~Hz}, 1 \mathrm{H}), 1.60(\mathrm{t}, J=5.6 \mathrm{~Hz}, 1 \mathrm{H}), 1.43(\mathrm{~d}, J=6.5 \mathrm{~Hz}, 3 \mathrm{H}), 1.38(\mathrm{~s}$, $3 \mathrm{H}), 1.28(\mathrm{t}, J=6.8 \mathrm{~Hz}, 3 \mathrm{H}), 1.25(\mathrm{~s}, 3 \mathrm{H}) .{ }^{13} \mathrm{C}-\mathrm{NMR}\left(126 \mathrm{MHz}, \mathrm{CDCl}_{3}\right) \delta: 181.4,154.3,148.2$, $147.5,146.2,126.8,126.6,124.2,120.7,119.8,118.8,117.4,107.8,55.2,50.9,50.2,46.5,39.2$, 37.6, 31.2, 30.9, 29.8, 28.2, 27.7, 26.9, 25.8, 22.0, 21.7, 19.8, 14.6. HRMS (ESI) $m / z:(\mathrm{M}+1 \mathrm{H})^{+}$ for $\mathrm{C}_{30} \mathrm{H}_{39} \mathrm{~N}_{2} \mathrm{O}$ calcd 443.3057; found 443.3062.

\section{2-bromo- $N$-(1-hydroxy-2-methylpropan-2-yl)benzamide (22):}

To a solution of thionyl chloride $(25 \mathrm{~mL})$ with 10 drops of DMF in a $100-\mathrm{mL}$ round-bottomed flask equipped with magnetic stirbar, 2-bromobenzoic acid (22) (5.0 g, $24.8 \mathrm{mmol})$ as a solid was slowly added. The resulting mixture was placed in a pre-heated oil bath at $80{ }^{\circ} \mathrm{C}$ and stirred at this temperature for 3 hours. Upon cooling to room temperature, the solvent was carefully removed by rotary evaporation. $\mathrm{CH}_{2} \mathrm{Cl}_{2}(50 \mathrm{~mL})$ was added and removed under reduced pressure. The crude reaction was placed under high vacuum for $1 \mathrm{~h}$. The solid was dissolved in $\mathrm{CH}_{2} \mathrm{Cl}_{2}(50 \mathrm{~mL})$ and added by addition funnel to a stirred solution of 2-amino-2-methylpropan-1-ol (5.3 mL, 55.5 mmol), DIPEA $(7.5 \mathrm{~mL}, 43.1 \mathrm{mmol})$, and $\mathrm{CH}_{2} \mathrm{Cl}_{2}(50 \mathrm{~mL})$ in a $250-\mathrm{mL}$ flame-dried roundbottomed flask cooled in a $0{ }^{\circ} \mathrm{C}$ ice bath. The reaction mixture was stirred overnight at room temperature. Saturated $\mathrm{NaHCO}_{3}$ aqueous solution $(100 \mathrm{~mL})$ was added to the reaction mixture, and the layers were separated. The aqeuous layer was further extracted with $\mathrm{CH}_{2} \mathrm{Cl}_{2}(3 \times 50 \mathrm{~mL})$ and the organic layers were combined and dried with $\mathrm{Na}_{2} \mathrm{SO}_{4}$, filtered, and evaporated to give 22 $(6.1 \mathrm{~g}, 22.3 \mathrm{mmol})$ as a white solid in $90 \%$ yield without further purification. This compound is known. ${ }^{4}{ }^{1} \mathrm{H}-\mathrm{NMR}\left(500 \mathrm{MHz}, \mathrm{CDCl}_{3}\right) \delta: 7.56(\mathrm{~d}, J=8.1 \mathrm{~Hz}, 1 \mathrm{H}), 7.47(\mathrm{~d}, J=7.6 \mathrm{~Hz}, 1 \mathrm{H}), 7.34(\mathrm{t}$, $(\mathrm{d}, J=7.4 \mathrm{~Hz}, 1 \mathrm{H}), 7.25\left(\mathrm{td},(\mathrm{d}, J=7.8 \mathrm{~Hz}, 1.7 \mathrm{~Hz}, 1 \mathrm{H}), 6.1(\mathrm{~s}, 1 \mathrm{H}), 4.4(\mathrm{~s}, 1 \mathrm{H}), 1.39(\mathrm{~s}, 6 \mathrm{H}) .{ }^{13} \mathrm{C}-\right.$ NMR (126 MHz, $\mathrm{CDCl}_{3}$ ) $\delta: 168.4,138.1,133.3,131.3,129.3,127.6,119.3,70.3,57.1,24.5$. HRMS (ESI) $m / z$ : $(\mathrm{M}+1 \mathrm{H})^{+}$for $\mathrm{C}_{11} \mathrm{H}_{15} \mathrm{NO}_{2} \mathrm{Br} 272.0281$; found 272.0286 .

\section{2-(2-bromophenyl)-4,4-dimethyl-4,5-dihydrooxazole (23):}

To a 50-mL round-bottomed flask equipped with a magnetic stir bar, 22 (5.0 g, $18.4 \mathrm{mmol})$ was charged. Thionyl chloride $(20 \mathrm{~mL})$ was added by syringe and the reaction was stirred at room temperature for 1.5 hours. ${ }^{4}$ The solvent was removed by rotary evaporation and the reaction diluted with water. Solid $\mathrm{NaHCO}_{3}$ was added slowly until $\mathrm{pH}$ 8. The aqueous layer was extracted with EtOAc $(3 \times 25 \mathrm{~mL})$, the organic extracts were combined, washed with brine $(1 \times 50 \mathrm{~mL})$, dried over $\mathrm{Na}_{2} \mathrm{SO}_{4}$, and filtered and concentrated. The reaction was purified with silica gel flash chromatography with 7:3 hexanes/EtOAc to neat EtOAc to give 23 (3.8 g, $15.1 \mathrm{mmol})$ in an 82\% yield. This compound is known. ${ }^{4} \mathrm{H}-\mathrm{NMR}\left(500 \mathrm{MHz}, \mathrm{CDCl}_{3}\right) \delta: 7.57(\mathrm{~d}, J=7.4 \mathrm{~Hz}, 1 \mathrm{H}), 7.54(\mathrm{~d}$, $J=8.0 \mathrm{~Hz}, 1 \mathrm{H}), 7.25(\mathrm{t}, J=7.7 \mathrm{~Hz}, 1 \mathrm{H}), 7.19(\mathrm{t}, J=7.7 \mathrm{~Hz}, 1 \mathrm{H}), 4.06(\mathrm{~s}, 2 \mathrm{H}), 1.33(\mathrm{~s}, 6 \mathrm{H}) .{ }^{13} \mathrm{C}-$ NMR (126 MHz, $\left.\mathrm{CDCl}_{3}\right) \delta: 160.7,132.6,130.5,130.2,129.3,126.0,120.8,78.4,67.1,27.2$. HRMS (ESI) $m / z:(\mathrm{M}+1 \mathrm{H})^{+}$for $\mathrm{C}_{11} \mathrm{H}_{13} \mathrm{NOBr}$ calcd 254.0175; found 254.0181.

\section{Benzoic Acid (8):}

To a flame-dried 25-mL round-bottomed flask flushed with argon and equipped with a magnetic stir bar was added a solution of aryl oxazole $23(481 \mathrm{mg}, 1.7 \mathrm{mmol})$ in anhydrous THF $(3 \mathrm{~mL})$. After cooling to $-78{ }^{\circ} \mathrm{C}, 1.7 \mathrm{M} t$-BuLi in hexanes $(1.1 \mathrm{~mL}, 1.87 \mathrm{mmol})$ was added dropwise and 
the resulting mixture was stirred for an additional 30 minutes at this temperature, generating the reactive intermediate. Ketone $6(117 \mathrm{mg}, 0.26 \mathrm{mmol})$, and $N, N, N$ ' $N$ '-tetramethylethylenediamine $(0.395 \mathrm{~mL}, 2.6 \mathrm{mmol})$ in anhydrous THF $(4 \mathrm{~mL})$ were cooled to $-78^{\circ} \mathrm{C}$ and added dropwise to the reaction mixture in four portions over 30 minutes by syringe. The dry ice/acetone bath $(500 \mathrm{~mL}$ capacity) was fully filled with dry ice, covered with tinfoil and cotton, and the reaction was left stirring overnight, coming to room temperature very slowly. The reaction was quenched by the addition of $\mathrm{AcOH}(1 \mathrm{~mL})$ in $\mathrm{MeOH}(5 \mathrm{~mL})$. The reaction was stirred for an additional 10 minutes at room temperature and concentrated by rotary evaporation. The reaction was taken up in methylene chloride $(20 \mathrm{~mL})$ and washed with water $(20 \mathrm{~mL})$. The aqueous layer was extracted with $\mathrm{CH}_{2} \mathrm{Cl}_{2}(2 \times 30 \mathrm{~mL})$, or until colorless. The organic extracts were combined and washed with brine $(1 \times 20 \mathrm{~mL})$, dried over $\mathrm{Na}_{2} \mathrm{SO}_{4}$, filtered and solvent removed by rotary evaporation. The crude blue solid was transferred to a $100-\mathrm{mL}$ round-bottomed flask with $30 \mathrm{~mL}$ of $6 \mathrm{~N} \mathrm{HCl}$ then placed in a pre-heated oil bath at $90{ }^{\circ} \mathrm{C}$ and stirred for 18 hours at this temperature. If oxazole remained after this time, the reaction duration was extended. Upon cooling to room temperature, the reaction was quenched by careful addition of solid $\mathrm{Na}_{2} \mathrm{CO}_{3}$, extracted with $\mathrm{CH}_{2} \mathrm{Cl}_{2}(3 \times 20 \mathrm{~mL})$ and the organic extracts were combined, dried over $\mathrm{Na}_{2} \mathrm{SO}_{4}$, filtered and concentrated. The reaction was purified with silica gel flash chromatography $\left(99: 1 \mathrm{CH}_{2} \mathrm{Cl}_{2} / \mathrm{MeOH}\right.$ to 91:9 $\left.\mathrm{CH}_{2} \mathrm{Cl}_{2} / \mathrm{MeOH}\right)$ giving $8(83.6 \mathrm{mg}, 0.14 \mathrm{mmol})$ as a dark blue solid in $54 \%$ yield, presumed to be the chloride salt. Note: unreacted ketone 6 could be isolated with these chromatography conditions by eluting 98:2 $\mathrm{CH}_{2} \mathrm{Cl}_{2} / \mathrm{MeOH}$ for an extended time prior to changing the gradient, if desired. ${ }^{1} \mathrm{H}-$ NMR (500 MHz, DMSO-d6) $\delta: 8.13(\mathrm{t}, J=6.8 \mathrm{~Hz}, 1 \mathrm{H}), 7.78(\mathrm{t}, J=7.8 \mathrm{~Hz}, 1 \mathrm{H}), 7.70(\mathrm{t}, J=7.9$ $\mathrm{Hz}, 1 \mathrm{H}), 7.28(\mathrm{~d}, J=7.6 \mathrm{~Hz}, 1 \mathrm{H}), 6.87(\mathrm{~s}, 1 \mathrm{H}), 6.55(\mathrm{~d}, J=31.2 \mathrm{~Hz}, 1 \mathrm{H}), 6.44(\mathrm{~s}, 1 \mathrm{H}), 4.07$ (broad $\mathrm{s}, 2 \mathrm{H}), 3.72-3.83(\mathrm{~m}, 1 \mathrm{H}), 3.57-3.67(\mathrm{~m}, 1 \mathrm{H}), 3.50(\mathrm{dd}, J=27.1 \mathrm{~Hz}, J=6.17 \mathrm{~Hz}, 4 \mathrm{H}), 2.61-2.70$ $(\mathrm{m}, 1 \mathrm{H}), 2.47-2.50(\mathrm{~m}, 2 \mathrm{H}), 1.95-2.00(\mathrm{~m}, 2 \mathrm{H}), 1.87(\mathrm{~s}, 3 \mathrm{H}), 1.79($ broad s, $6 \mathrm{H}), 1.39(\mathrm{q}, J=6.3$ $\mathrm{Hz}, 4 \mathrm{H}), 1.25$ (dd, $J=11.3 \mathrm{~Hz}, J=6.2 \mathrm{~Hz}, 6 \mathrm{H}), 0.88(\mathrm{t}, J=8.4 \mathrm{~Hz}, 3 \mathrm{H}){ }^{13} \mathrm{C}-\mathrm{NMR}(126 \mathrm{MHz}$, DMSO-d $\left.d_{6}\right) \delta: 166.6,132.8,130.5,129.8,128.9,128.2,123.0,123.0,122.9,122.8,120.3,118.1$, 111.2,79.3, 57.7, 51.9, 51.3, 44.7, 31.0, 30.7, 30.6, 30.3, 29.0, 28.9, 27.5, 27.4, 26.1, 26.0, 25.9, 20.7, 20.5, 18.9, 18.7, 14.5. HRMS (ESI) $m / z$ : $(\mathrm{M}+)^{+}$for $\mathrm{C}_{37} \mathrm{H}_{43} \mathrm{~N}_{2} \mathrm{O}_{2}$ calcd 547.3319; found 547.3318 .

Note: The NMR spectra were evaluated in DMSO- $d_{6}$, the ortho carboxylic acid is known to lactonize in aprotic conditions and this was observed. The ESI ${ }^{+}$HRMS was evaluated in $\mathrm{MeOH} / \mathrm{H}_{2} \mathrm{O}$, promoting the open form and was thus observed in that analysis.

\section{ATTO 647N Methyl Ester (24):}

Benzoic acid 8 (50 $\mathrm{mg}, 0.085 \mathrm{mmol})$ was charged to a flame-dried $25 \mathrm{~mL}$ round-bottomed flask equipped with a magnetic stirbar and placed under argon. Anhydrous 1,2-dichloroethane (9 mL) was added via syringe followed by $\mathrm{POCl}_{3}(300 \mathrm{uL}, 3.2 \mathrm{mmol})$ also by syringe. The reaction was placed in a preheated oil bath $\left(75^{\circ} \mathrm{C}\right)$ and stirred for 2 hours. After cooling to room temperature, the solvent was removed by rotary evaporation. $\mathrm{CH}_{2} \mathrm{Cl}_{2}(20 \mathrm{~mL})$ was added and removed by rotary evaporation, and then placed under high vacuum $(25 \mathrm{~mm} \mathrm{Hg})$ for one hour. To the round-bottomed flask, anhydrous methylene chloride $(3 \mathrm{~mL})$ was added by syringe and the reaction was placed in an external ice bath $\left(-15^{\circ} \mathrm{C}\right.$; ethylene glycol and dry ice). Separately, a solution of 4(methylamino)butyric acid hydrochloride $(114 \mathrm{mg}, 0.75 \mathrm{mmol})$ in methylene chloride $(3 \mathrm{~mL})$ with triethylamine $(150 \mathrm{uL}, 1.1 \mathrm{mmol})$ was prepared. After the reaction mixture had stirred for 10 minutes in the external bath, the free-based amine was added via syringe in one addition. The reaction was stirred at the same temperature for 20 minutes and then allowed to warm to $23^{\circ} \mathrm{C}$ and 
stirred for an additional 20 minutes. $1 \mathrm{~N} \mathrm{HCl}(5 \mathrm{~mL})$ was added by syringe and the two layers separated. The aqueous layer was further extracted with methylene chloride $(2 \times 10 \mathrm{~mL})$. The organic layers were combined, washed with brine $(1 \times 5 \mathrm{~mL})$ and dried over $\mathrm{Na}_{2} \mathrm{SO}_{4}$. The solvent was removed by rotary evaporation and the crude methyl ester was taken directly to the next reaction without purification. (SI-42 for LCMS trace). LRMS (ESI) $m / z$ : $(\mathrm{M}+)^{+}$for $\mathrm{C}_{43} \mathrm{H}_{54} \mathrm{~N}_{3} \mathrm{O}_{3}$ calcd 660.42 found 660.4. Note: two peaks are observable in the absorbance trace of the LCMS, corresponding to the two inseparable atropisomers of $\mathbf{2 4}$.

\section{Carboxy ATTO 647N (2):}

To a $50 \mathrm{~mL}$ round-bottomed flask equipped with a magnetic stir bar, crude methyl ester $\mathbf{2 4}(0.085$ mmol) was charged. THF $(15 \mathrm{~mL})$ was added by syringe followed by DI water $(10 \mathrm{~mL})$. The reaction was placed in a pre-cooled ice bath $\left(0{ }^{\circ} \mathrm{C}\right)$ and stirred for 10 minutes. A solution of $1 \mathrm{~N}$ $\mathrm{NaOH}(0.425 \mathrm{~mL}, 0.425 \mathrm{mmol})$ was added by syringe and the reaction stirred at this same temperature for 3 hours and then acidified with glacial $\mathrm{AcOH}(0.5 \mathrm{~mL}, 8.75 \mathrm{mmol})$. The reaction was concentrated by rotary evaporation and then purified by reverse phase preparatory HPLC (3:1 $\mathrm{CH}_{3} \mathrm{CN} / \mathrm{H}_{2} \mathrm{O}$ with $0.1 \% \mathrm{H}_{2} \mathrm{CO}_{2}$ ) to give inseparable atropisomers of the title compound 2 as a dark blue solid (54 mg, $0.078 \mathrm{mmol}$ ) in $91 \%$ yield for the two steps. ${ }^{1} \mathrm{H}-\mathrm{NMR}\left(500 \mathrm{MHz}, \mathrm{CD}_{3} \mathrm{OD}\right) \delta$ : $8.51(\mathrm{~s}, 1 \mathrm{H}), 7.66(\mathrm{t}, J=4.8 \mathrm{~Hz}, 2 \mathrm{H}), 7.55-7.58(\mathrm{~m}, 1 \mathrm{H}), 7.34-7.39(\mathrm{~m}, 1 \mathrm{H}), 6.90(\mathrm{~s}, 1 \mathrm{H}), 6.78$ (d, $J=16.9 \mathrm{~Hz}, 2 \mathrm{H}), 3.79-3.85(\mathrm{~m}, 1 \mathrm{H}), 3.64(\mathrm{t}, J=7.5 \mathrm{~Hz}, 2 \mathrm{H}), 3.56(\mathrm{~d}, J=6.5 \mathrm{~Hz}, 2 \mathrm{H}), 3.53$ $(J=5.2 \mathrm{~Hz}, 2 \mathrm{H}), 3.41-3.48(\mathrm{~m}, 1 \mathrm{H}), 3.30(\mathrm{~s}, 3 \mathrm{H}), 3.17(\mathrm{t}, J=5.9 \mathrm{~Hz}, 2 \mathrm{H}), 3.05-3.15(\mathrm{~m}, 2 \mathrm{H})$, $2.87(\mathrm{~d}, J=25.1 \mathrm{~Hz}, 3 \mathrm{H}), 3 \mathrm{H}), 2.71-2.79(\mathrm{~m}, 1 \mathrm{H}), 2.57(\mathrm{~d}, J=18.5 \mathrm{~Hz}, 2 \mathrm{H}), 1.97-2.08(\mathrm{~m}$, $4 \mathrm{H}), 1.88(\mathrm{~d}, J=6.8 \mathrm{~Hz}, 3 \mathrm{H}), 1.82(\mathrm{~d}, J=6.8 \mathrm{~Hz}, 3 \mathrm{H}), 1.70(\mathrm{~d}, J=18.2 \mathrm{~Hz}, 2 \mathrm{H}), 1.46(\mathrm{~s}, 3 \mathrm{H})$ $1.33(\mathrm{~s}, 6 \mathrm{H}), 1.27(\mathrm{~s}, 2 \mathrm{H}), 1.01(\mathrm{t}, J=8.4 \mathrm{~Hz}, 3 \mathrm{H}) .{ }^{13} \mathrm{C}-\mathrm{NMR}\left(126 \mathrm{MHz}, \mathrm{CD}_{3} \mathrm{OD}\right) \delta: 169.8,169.2$, $160.8,160.7,157.8,157.8,153.3,153.2,152.2,150.0,149.9,136.1,136.0,135.4,135.1,134.6$, $134.5,130.9,130.6,130.4,130.2,128.8,128.7,128.6,128.2,126.8,126.8,123.3,122.9,122.8$, 120.6, 119.0, 111.3, 111.3, 69.9, 57.6, 57.5, 51.8, 51.1, 46.1, 44.9, 44.8, 40.4, 39.7, 39.6, 36.8, $36.6,31.1,30.3,30.1,29.7,29.4,29.0,27.2,27.1,26.1,26.1,24.9,24.7,22.2,22.1,20.3,20.2$, 18.0, 17.5, 13.4, 13.3. FTIR (powder): 2992, 2928, 1622, 1592, 1450, 1425, 1313, $1168 \mathrm{~cm}^{-1}$. HRMS (ESI) $m / z(\mathrm{M}+)^{+}$for $\mathrm{C}_{42} \mathrm{H}_{52} \mathrm{~N}_{3} \mathrm{O}_{3}$ calcd 646.4003; found 646.4006 . 
${ }^{1} \mathrm{H} \mathrm{NMR}, \mathrm{CDCl}_{3}, 500 \mathrm{MHz}$

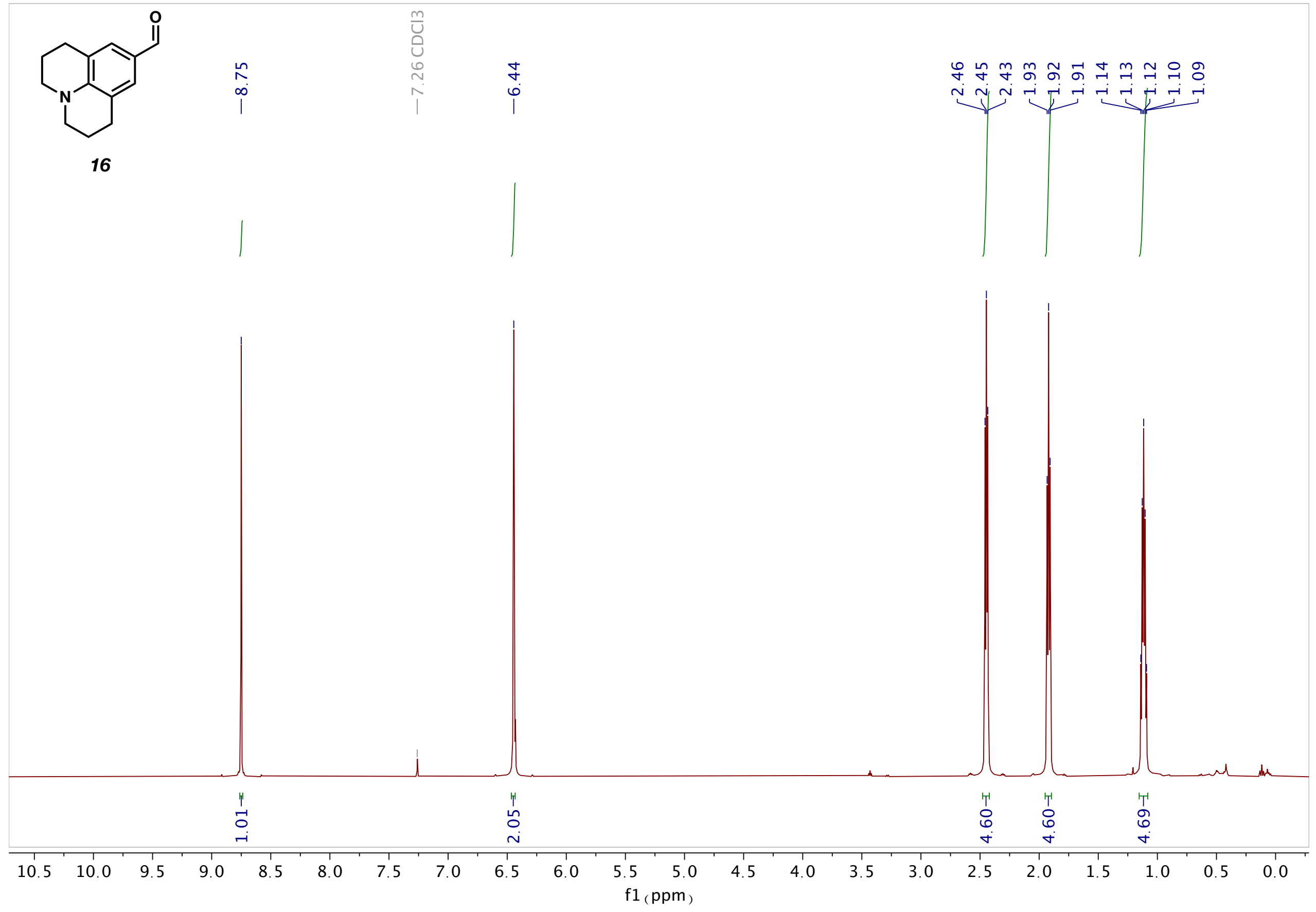


${ }^{13} \mathrm{C} \mathrm{NMR}, \mathrm{CDCl}_{3}, 126 \mathrm{MHz}$
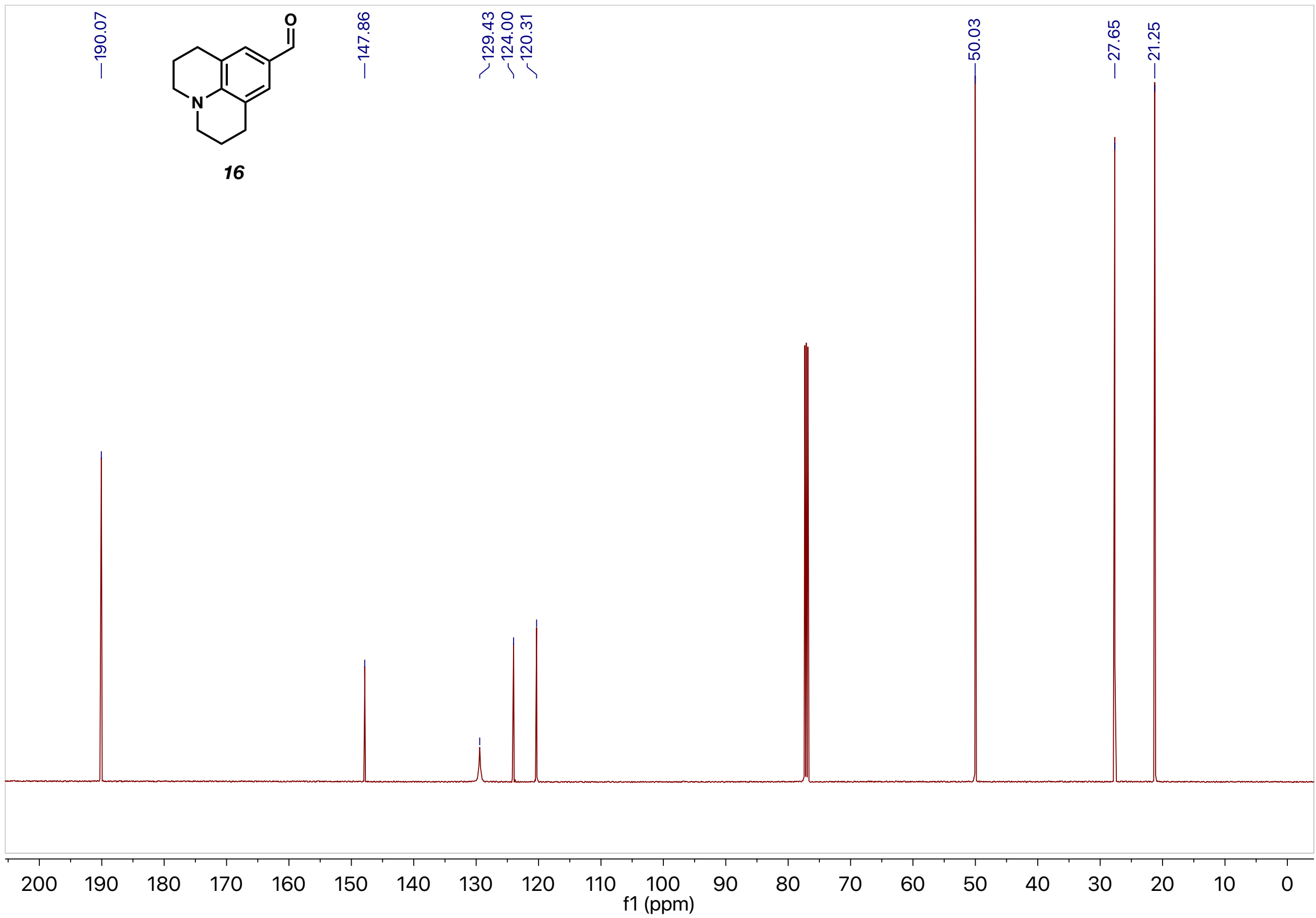
${ }^{1} \mathrm{H} \mathrm{NMR}, \mathrm{CDCl}_{3}, 500 \mathrm{MHz}$

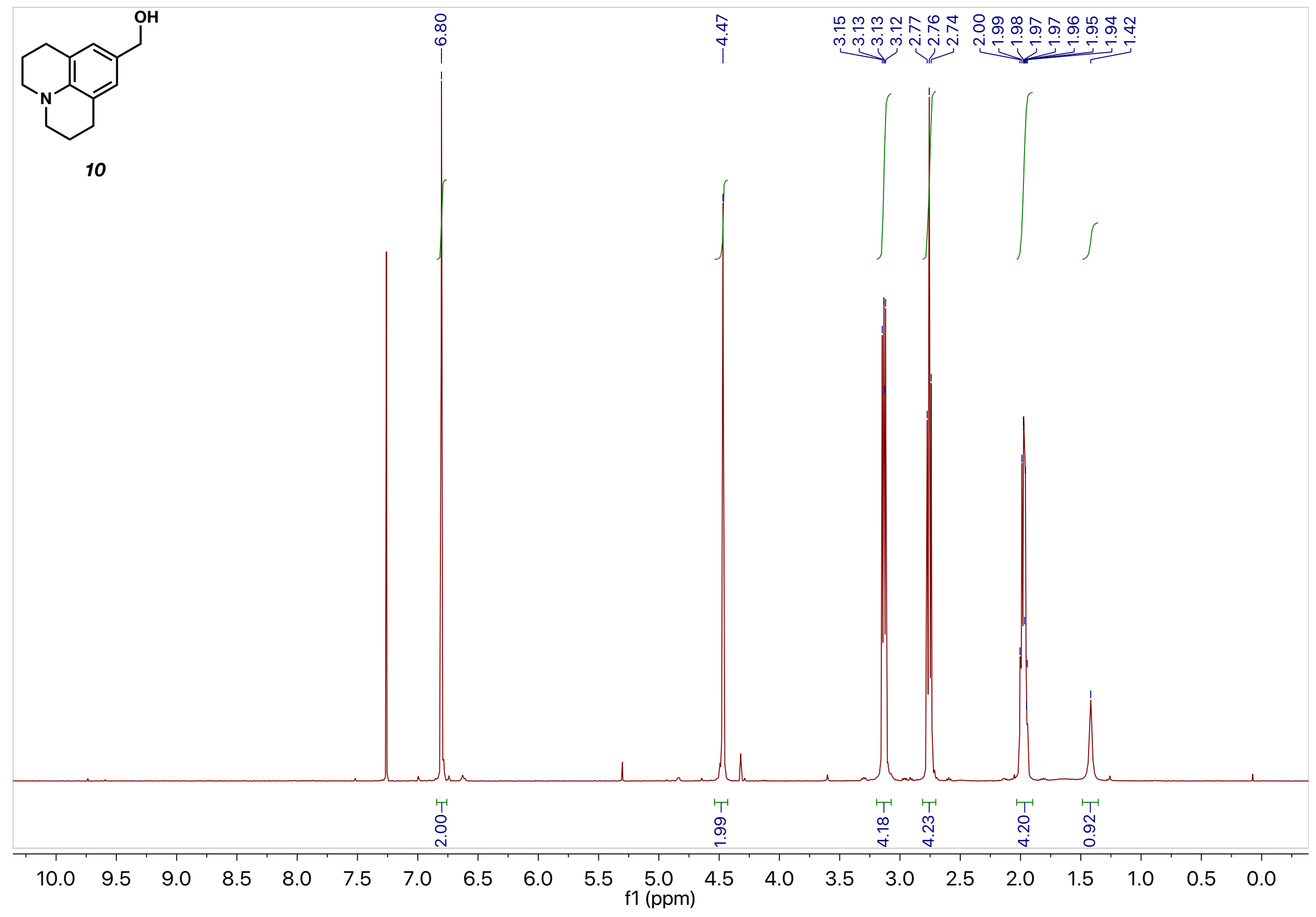


${ }^{13} \mathrm{C} \mathrm{NMR}, \mathrm{CD}_{3} \mathrm{OD}, 126 \mathrm{MHz}$
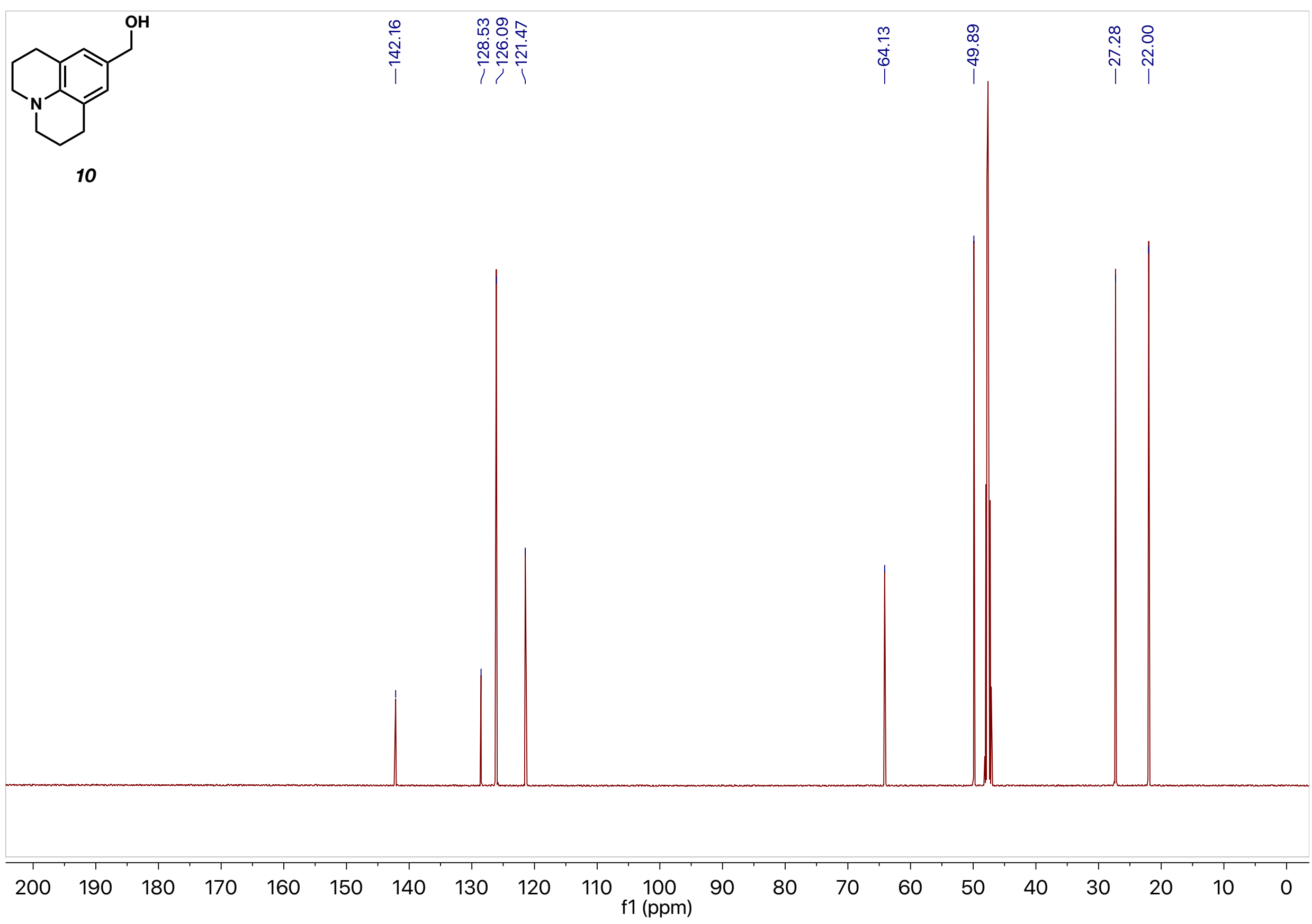
${ }^{1} \mathrm{H} \mathrm{NMR}, \mathrm{CDCl}_{3}, 500 \mathrm{MHz}$

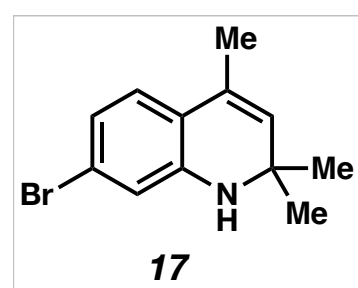

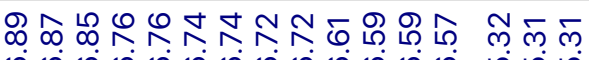

ن

న్

$\stackrel{\curvearrowright}{\text { i }}$

广̊ำ

$\iint 1$
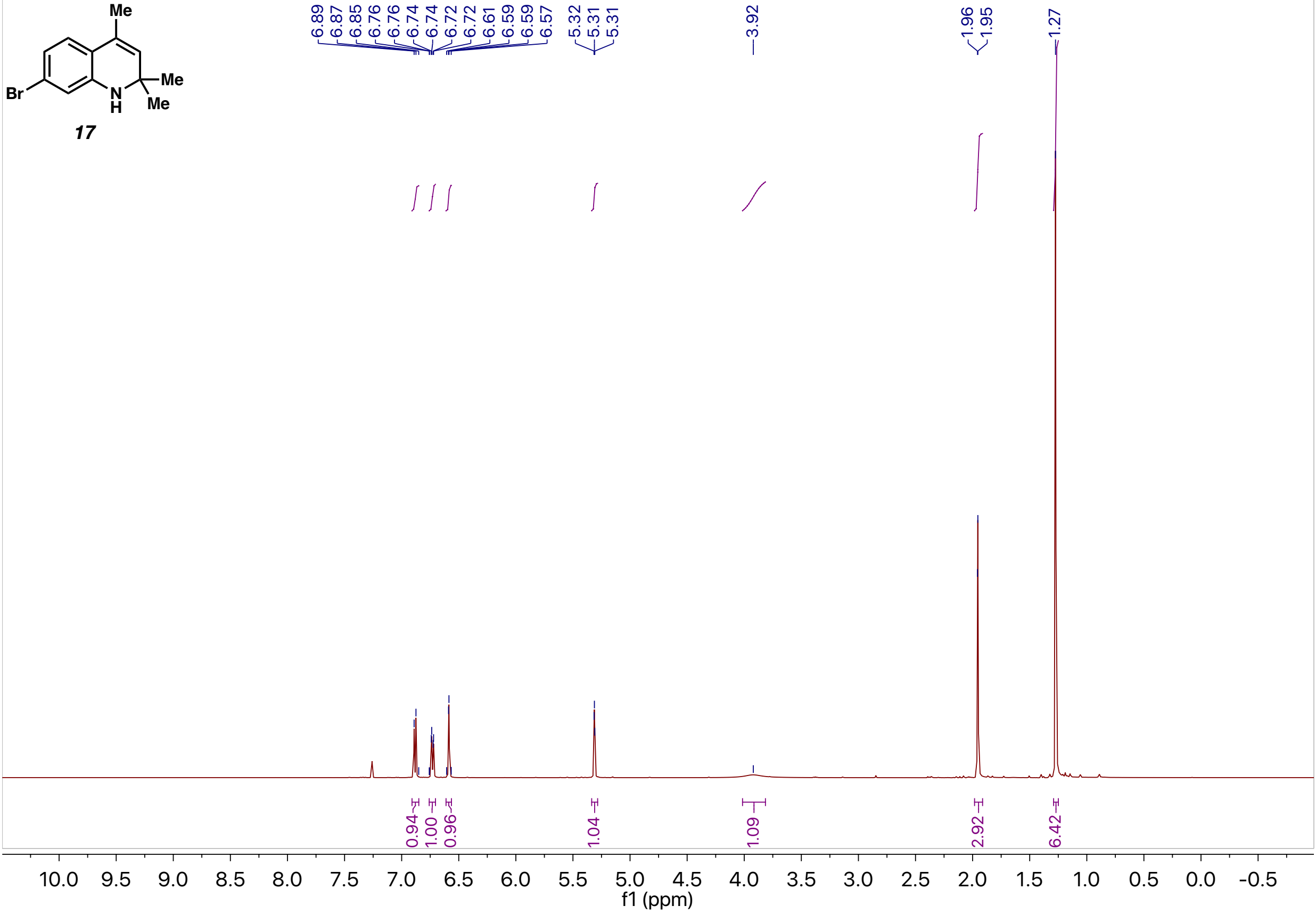
${ }^{13} \mathrm{C} \mathrm{NMR} \mathrm{CDCl}_{3}, 126 \mathrm{MHz}$
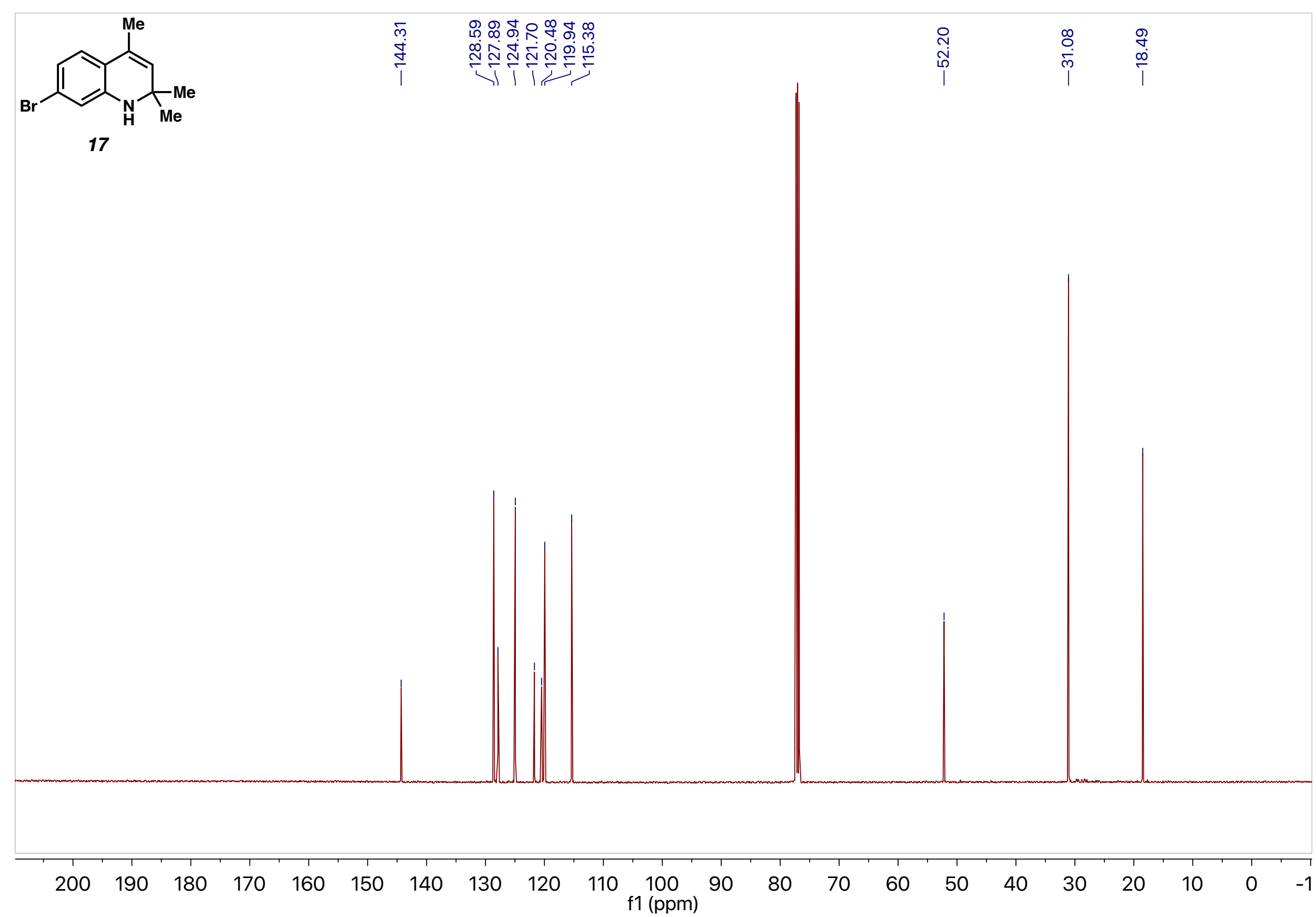
${ }^{1} \mathrm{H} \mathrm{NMR}, \mathrm{CDCl}_{3}, 500 \mathrm{MHz}$

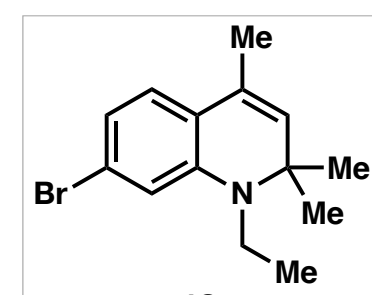

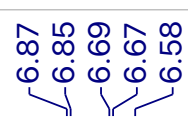

\section{$\overline{\sin }$}

हुํำ

लूm

范

12
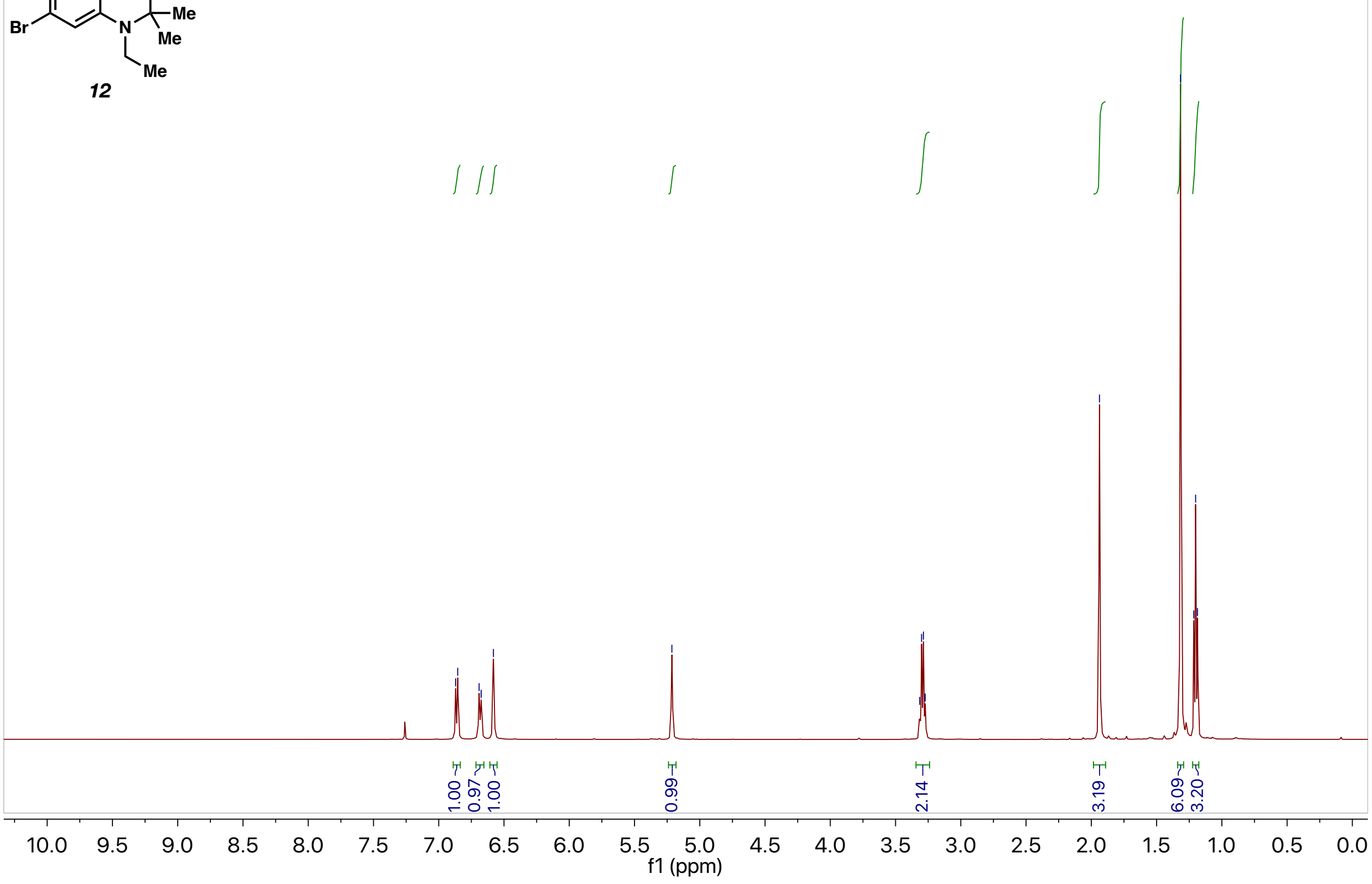
${ }^{13} \mathrm{C} \mathrm{NMR}_{\mathrm{NDCl}}, 126 \mathrm{MHz}$
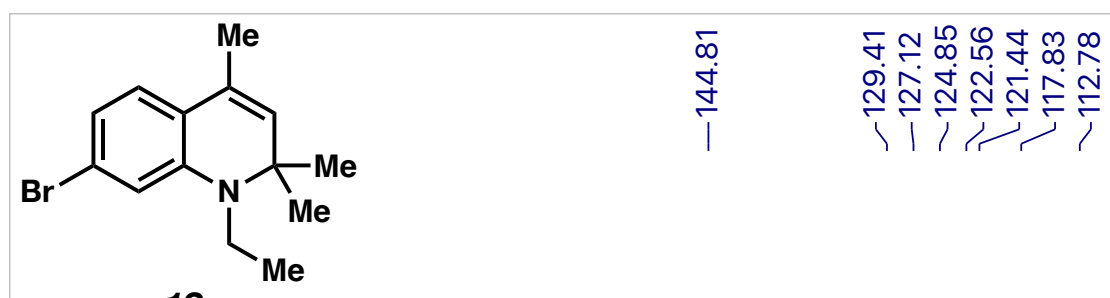

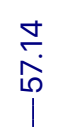

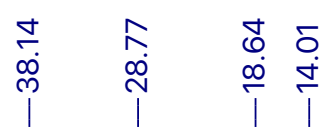

12
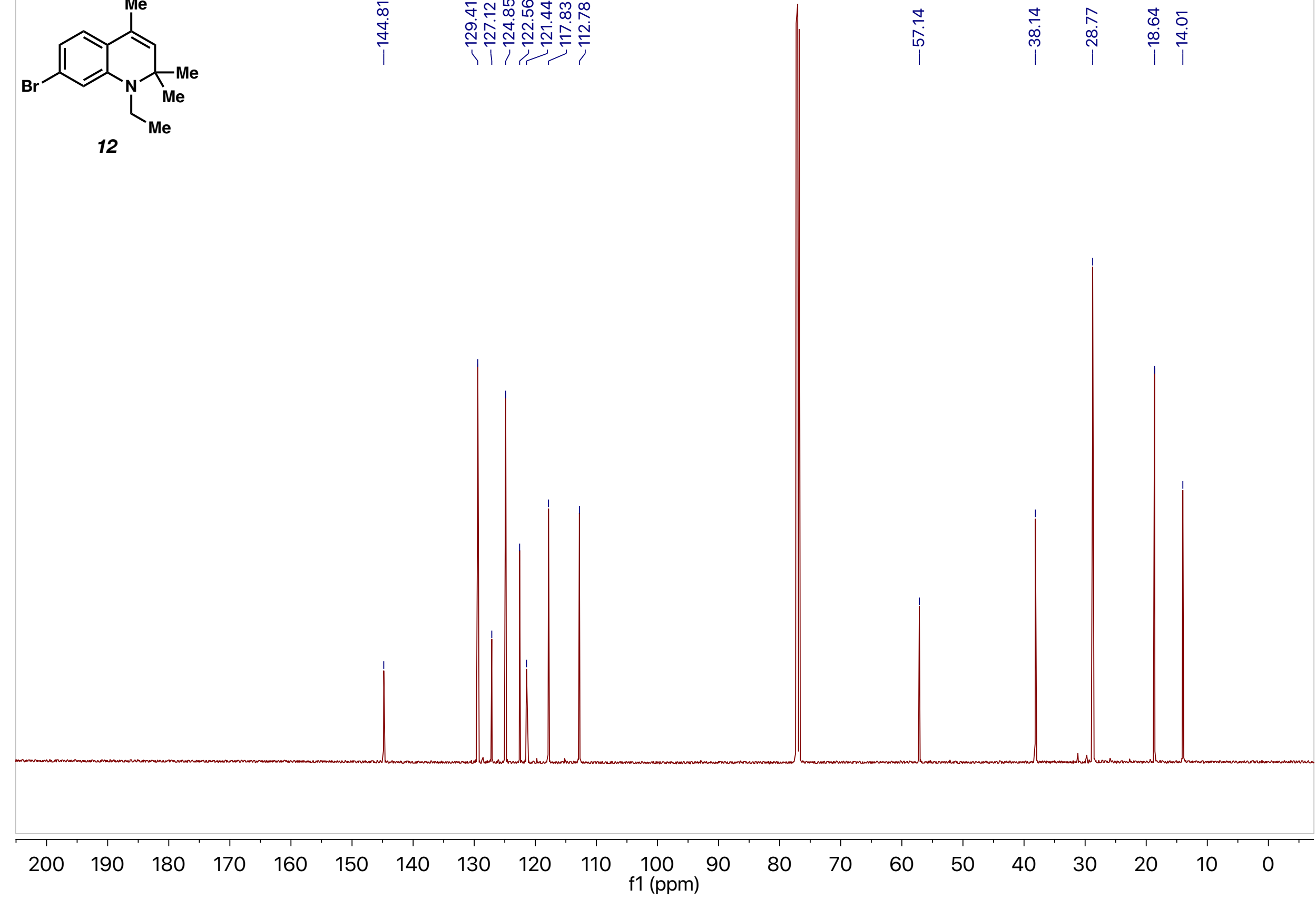
${ }^{1} \mathrm{H} \mathrm{NMR}, \mathrm{CDCl}_{3}, 500 \mathrm{MHz}$

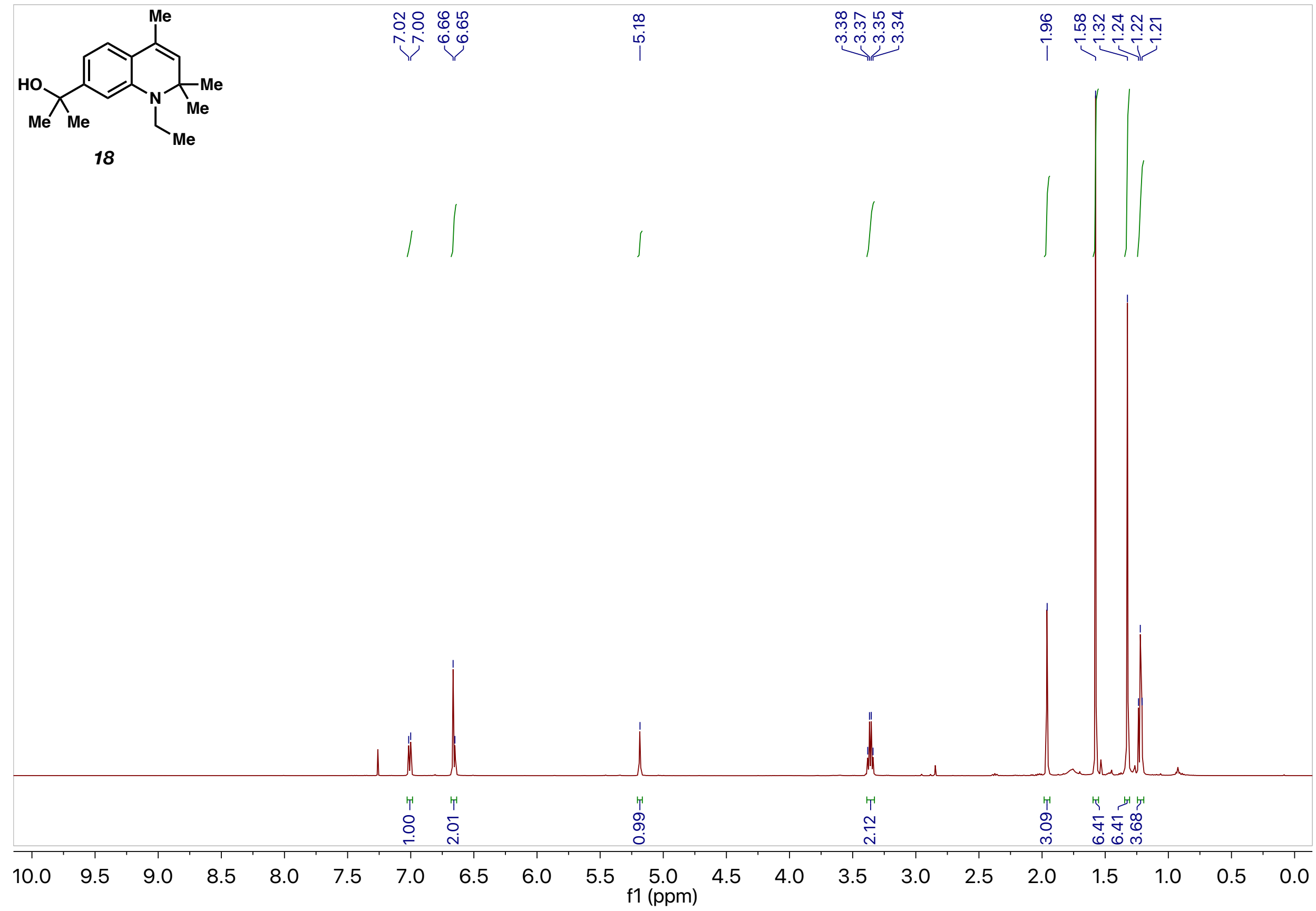


${ }^{13} \mathrm{C} \mathrm{NMR} \mathrm{CDCl}_{3}, 126 \mathrm{MHz}$
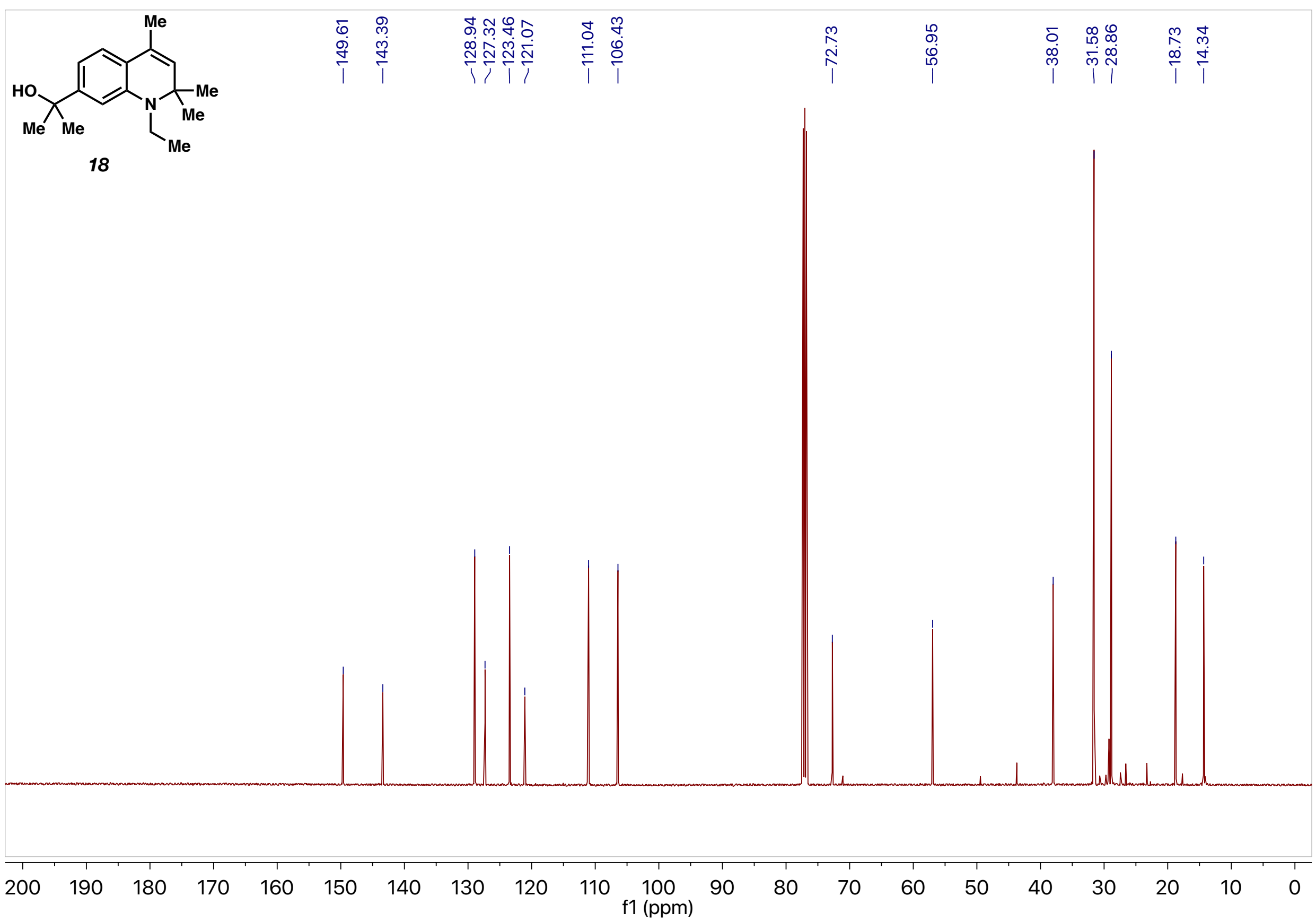
${ }^{1} \mathrm{H}$ NMR, $\mathrm{CDCl}_{3}, 400 \mathrm{MHz}$

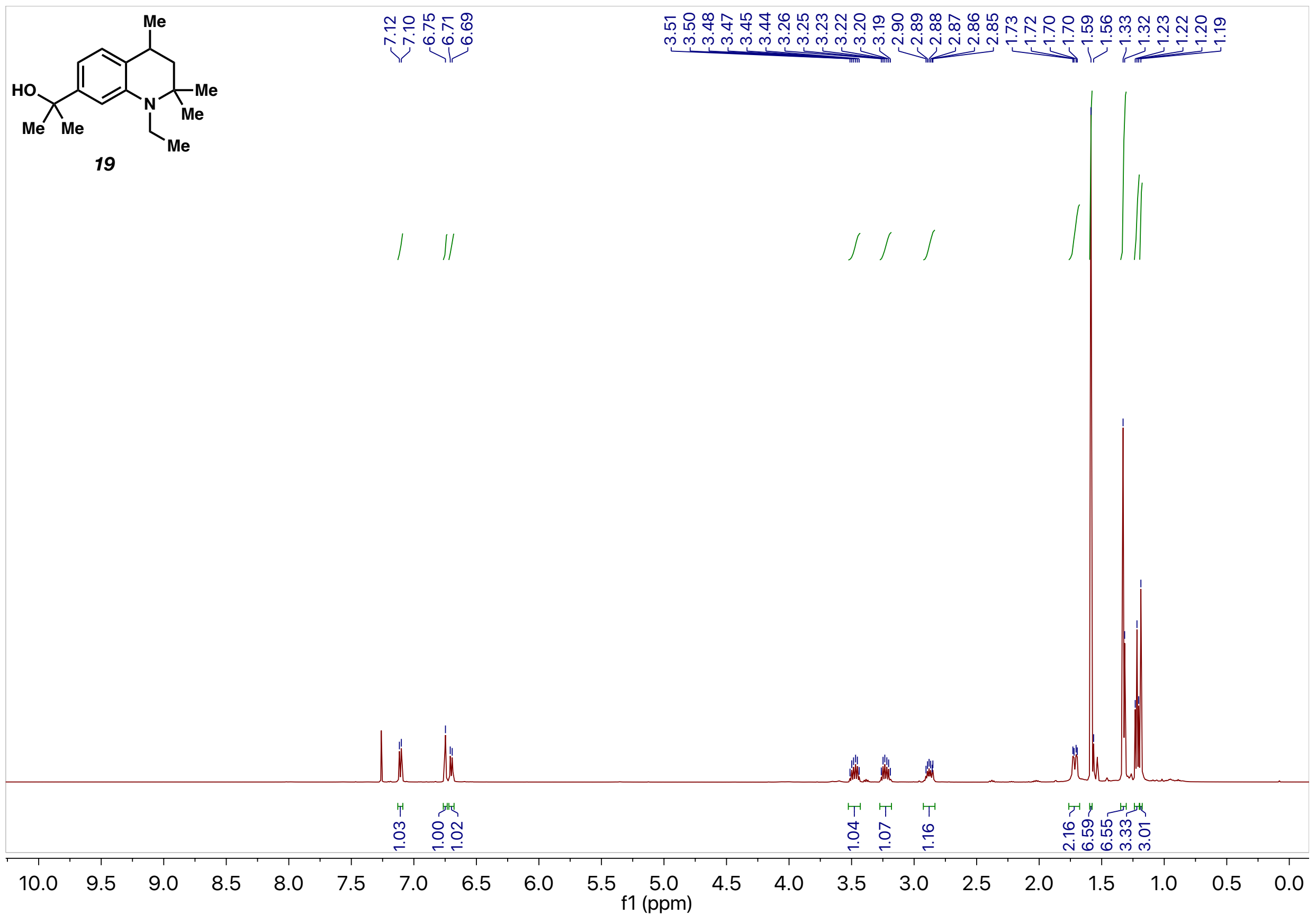


${ }^{13} \mathrm{C} \mathrm{NMR}, \mathrm{CDCl}_{3}, 126 \mathrm{MHz}$
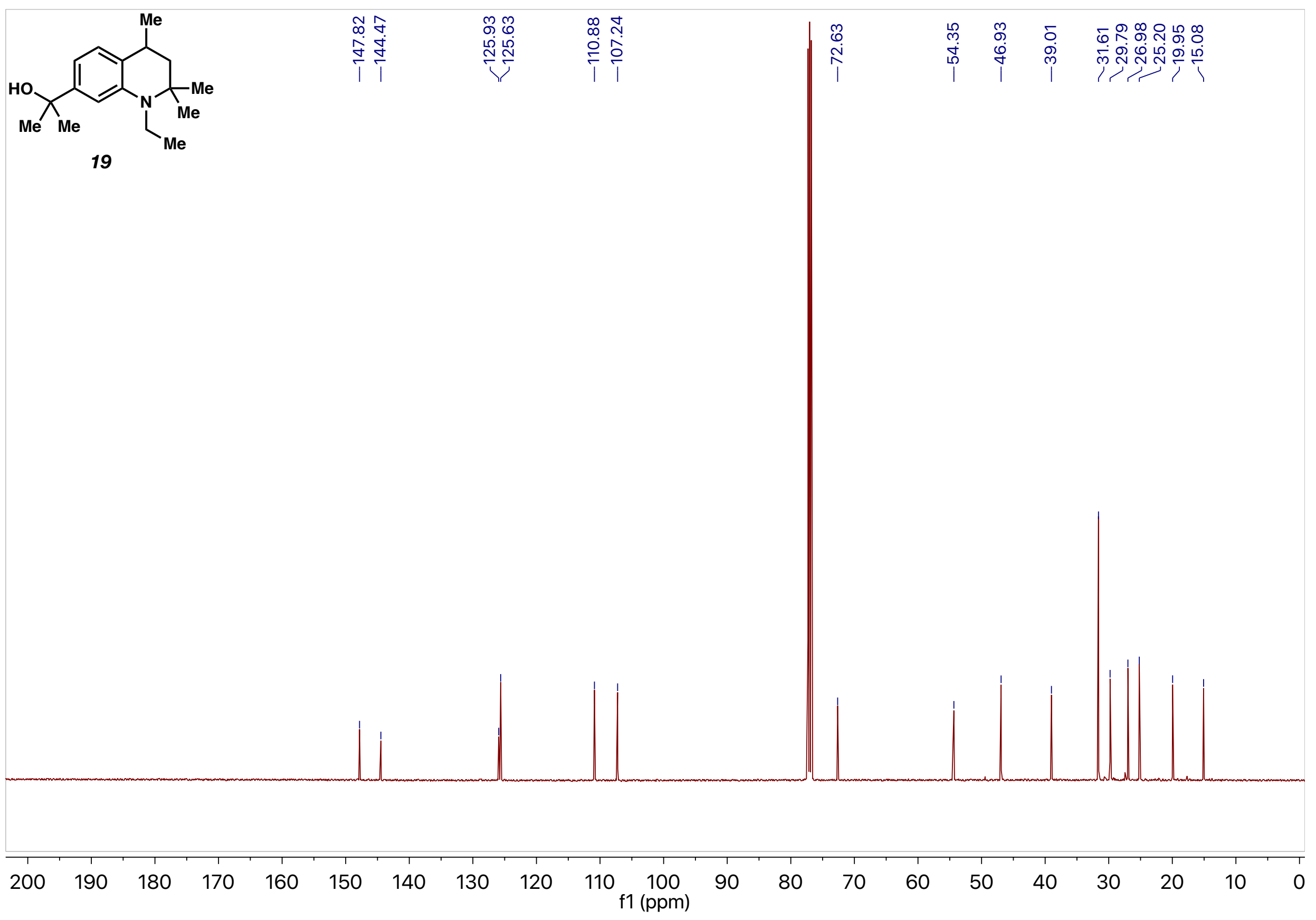
${ }^{1} \mathrm{H} \mathrm{NMR}, \mathrm{CDCl}_{3}, 500 \mathrm{MHz}$

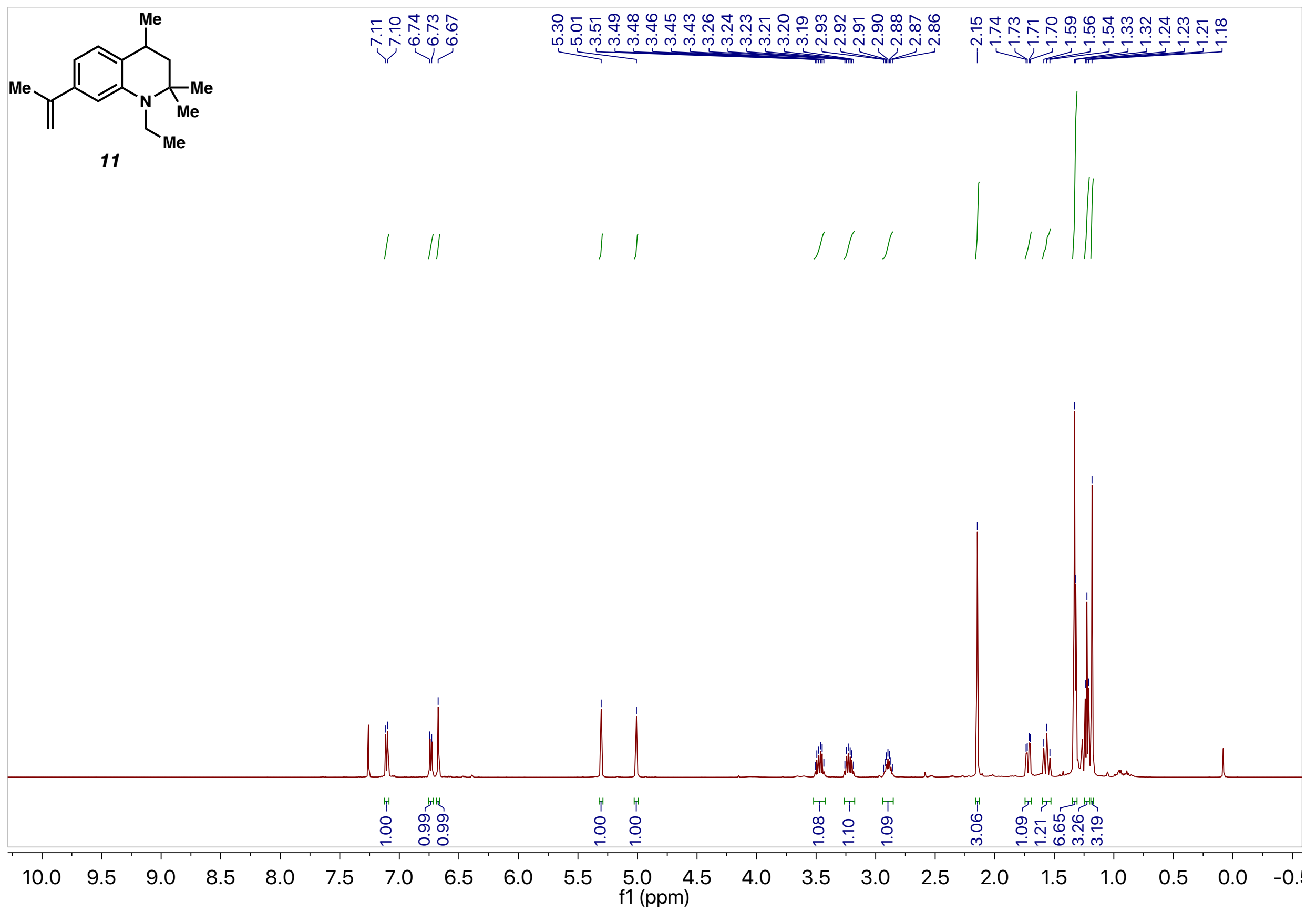


${ }^{13} \mathrm{C} \mathrm{NMR}, \mathrm{CDCl}_{3}, 126 \mathrm{MHz}$

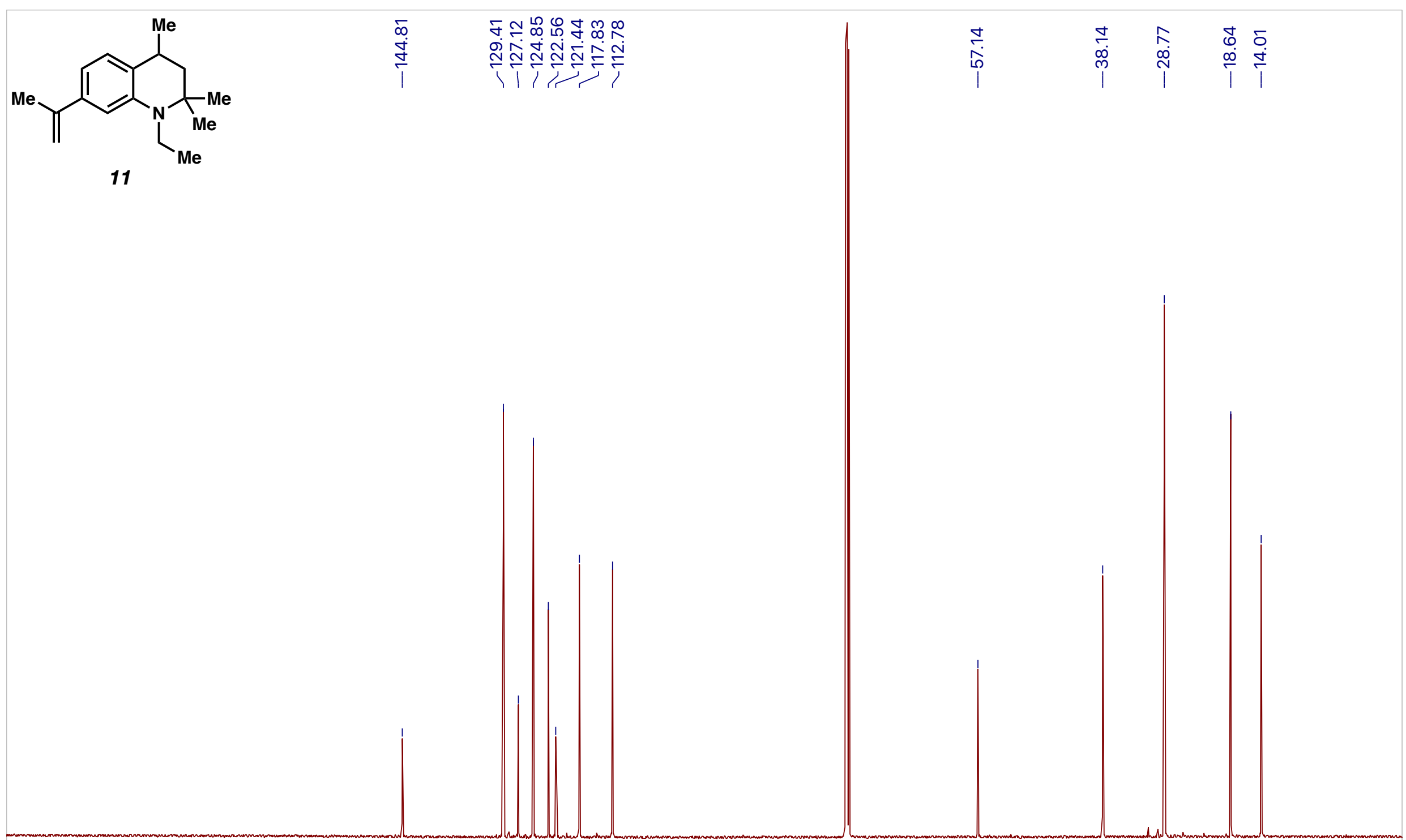

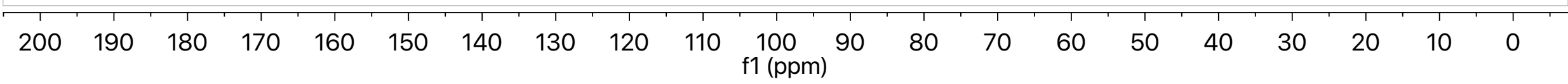


${ }^{1} \mathrm{H} \mathrm{NMR}, \mathrm{CDCl}_{3}, 500 \mathrm{MHz}$

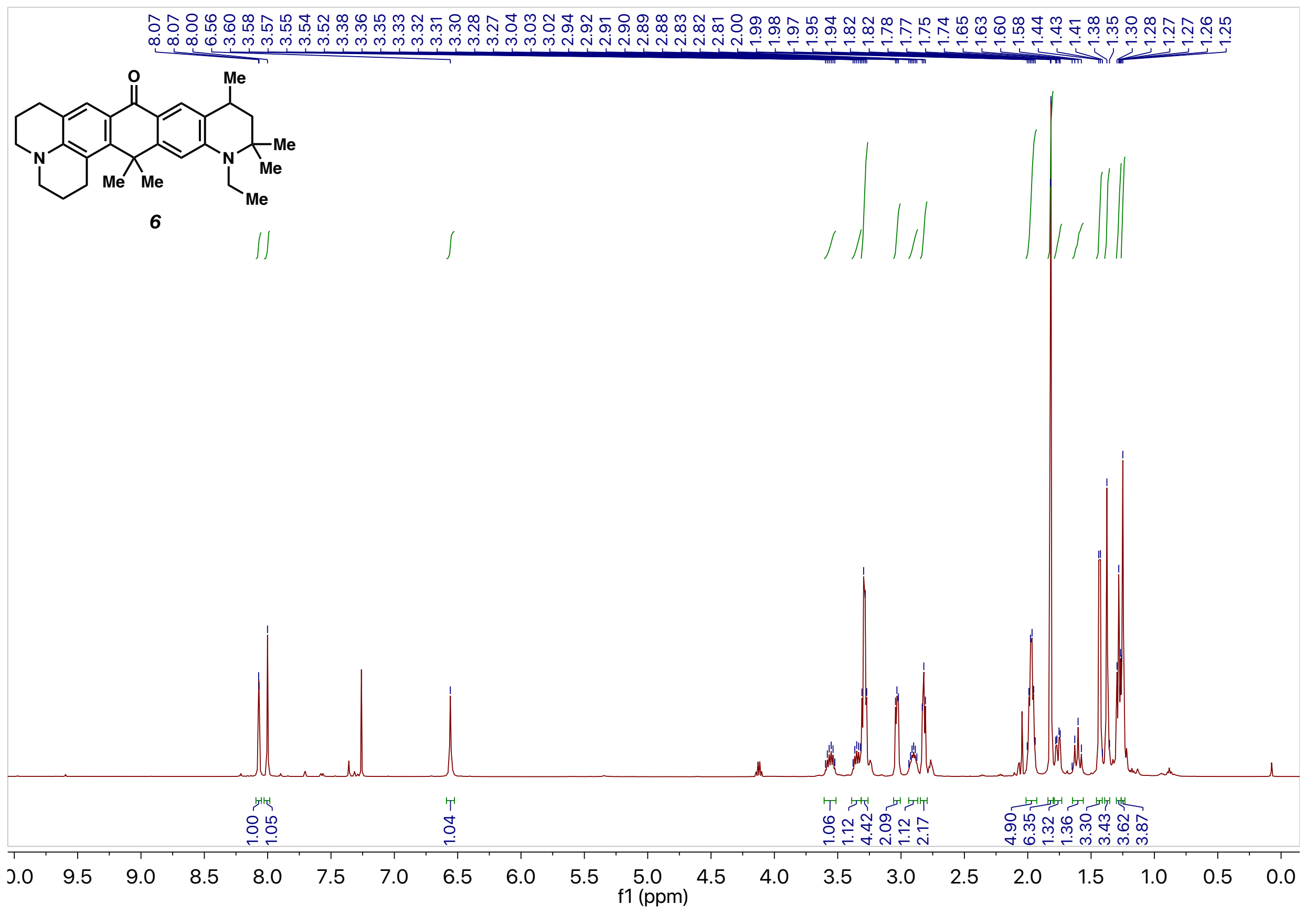


${ }^{13} \mathrm{C} \mathrm{NMR}, \mathrm{CDCl}_{3}, 126 \mathrm{MHz}$

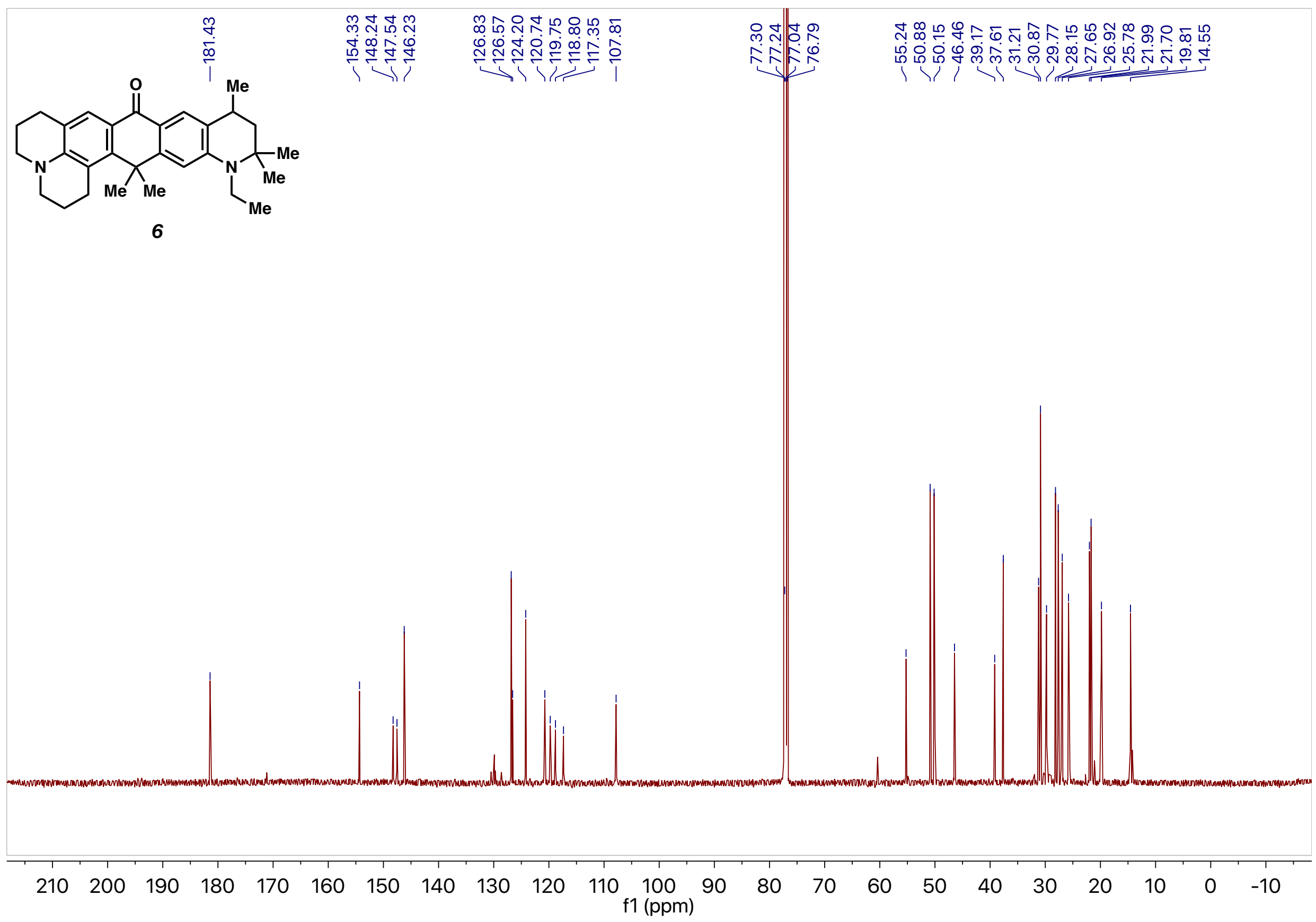


${ }^{1} \mathrm{H} \mathrm{NMR}, \mathrm{CDCl}_{3}, 500 \mathrm{MHz}$

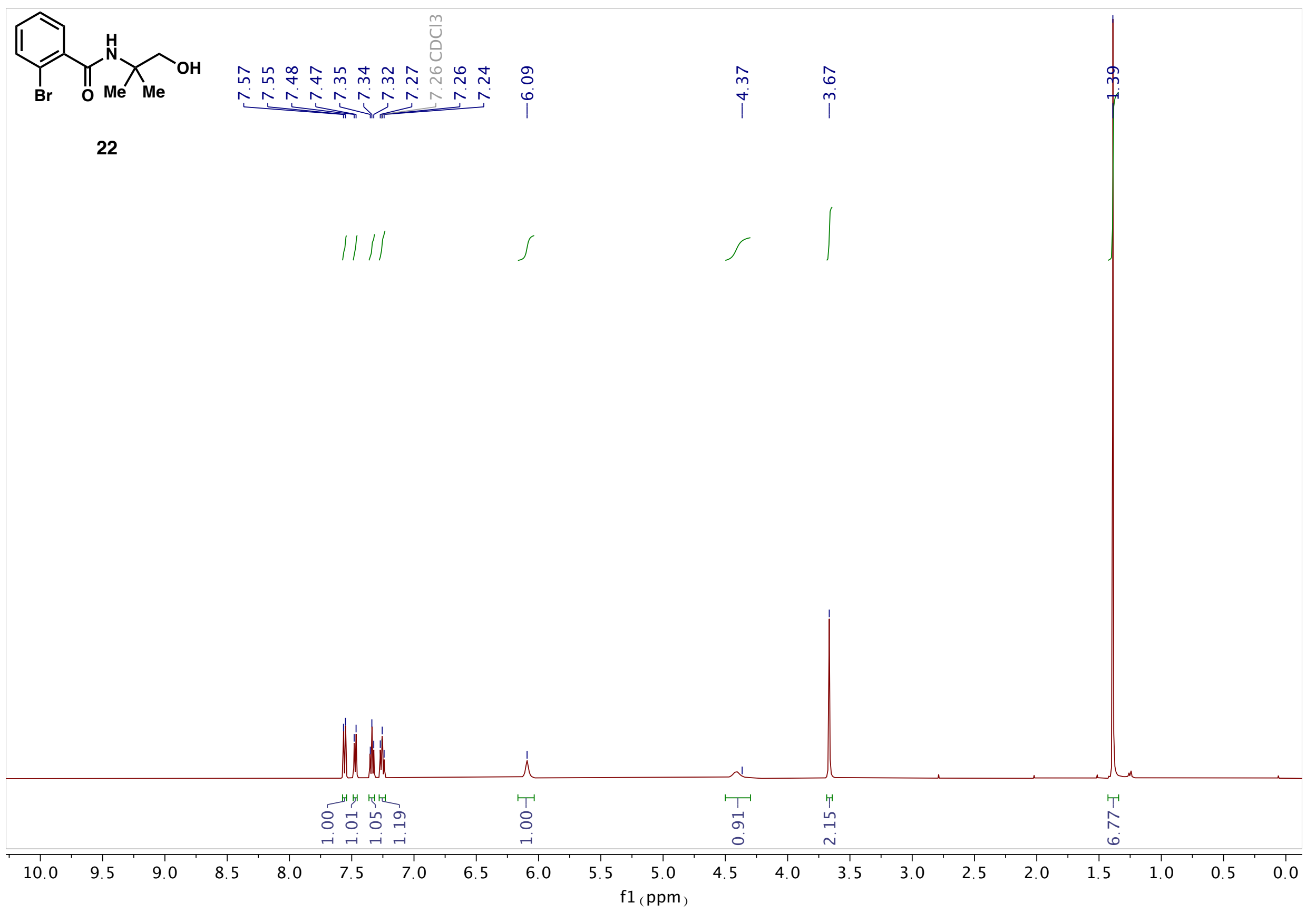


${ }^{13} \mathrm{C} \mathrm{NMR}, \mathrm{CDCl}_{3}, 126 \mathrm{MHz}$

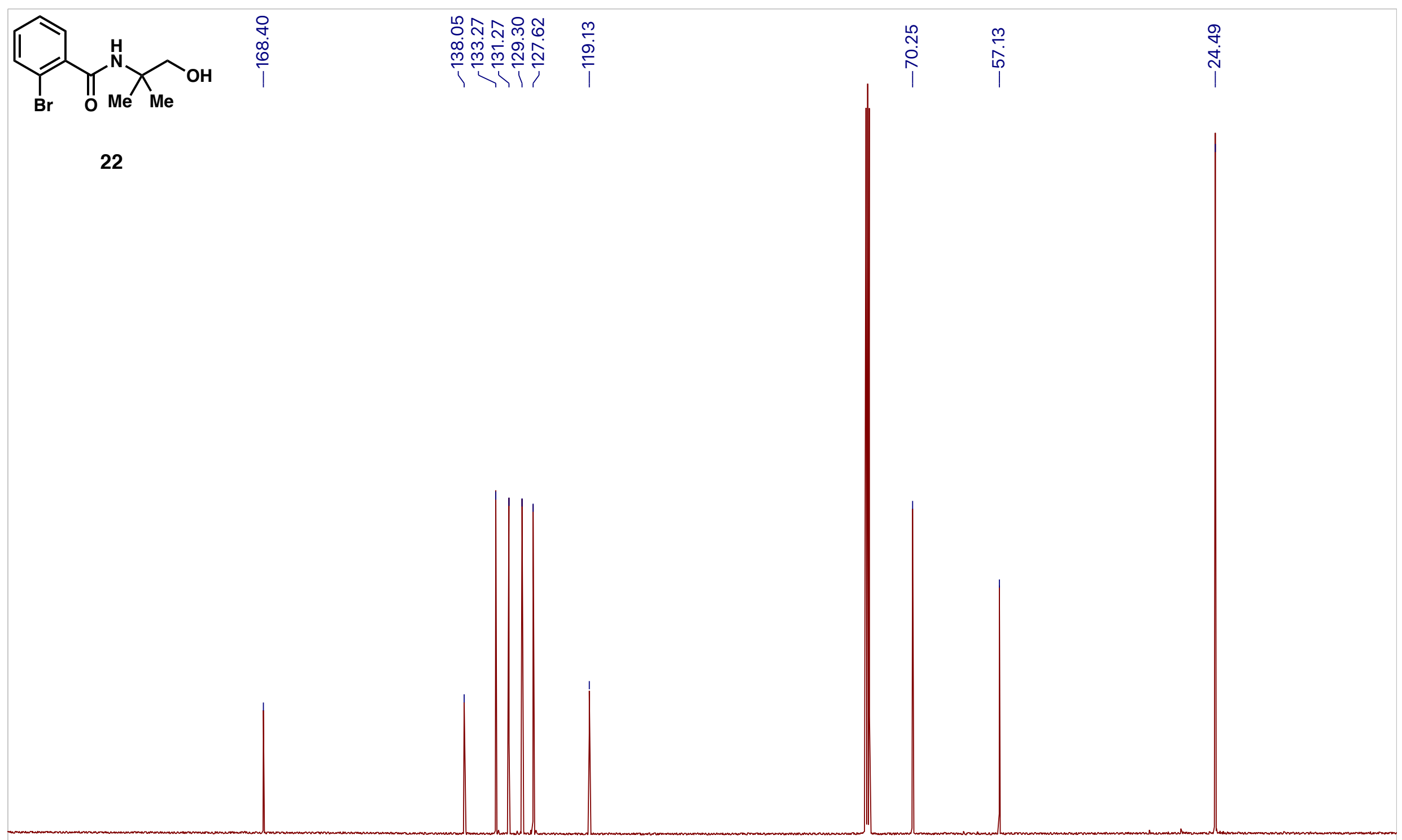

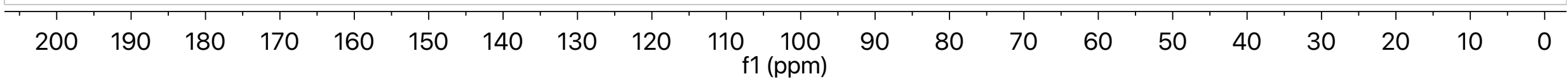


${ }^{1} \mathrm{H} \mathrm{NMR}, \mathrm{CDCl}_{3}, 500 \mathrm{MHz}$

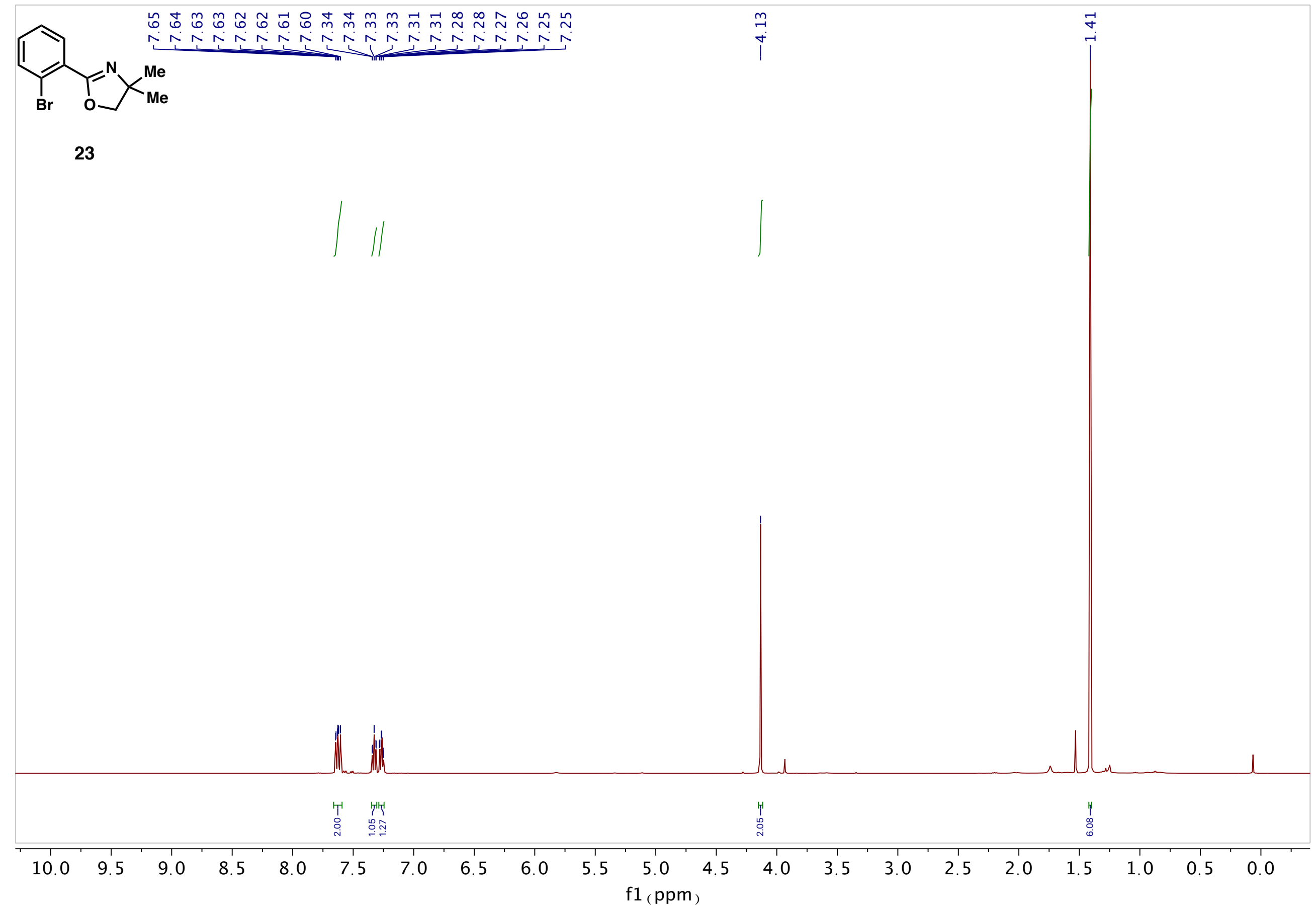


${ }^{13} \mathrm{C} \mathrm{NMR}, \mathrm{CDCl}_{3}, 126 \mathrm{MHz}$

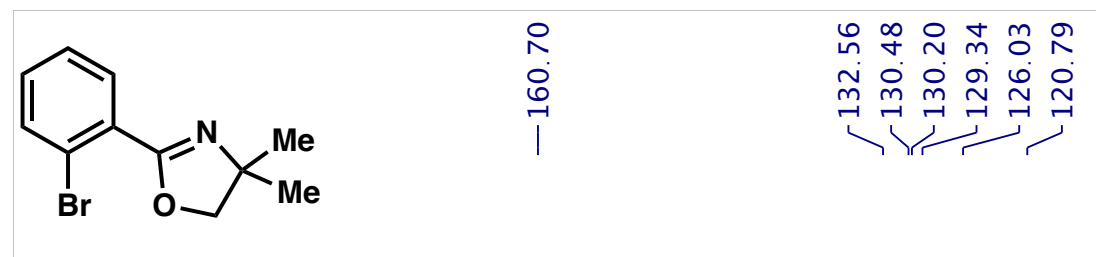

23
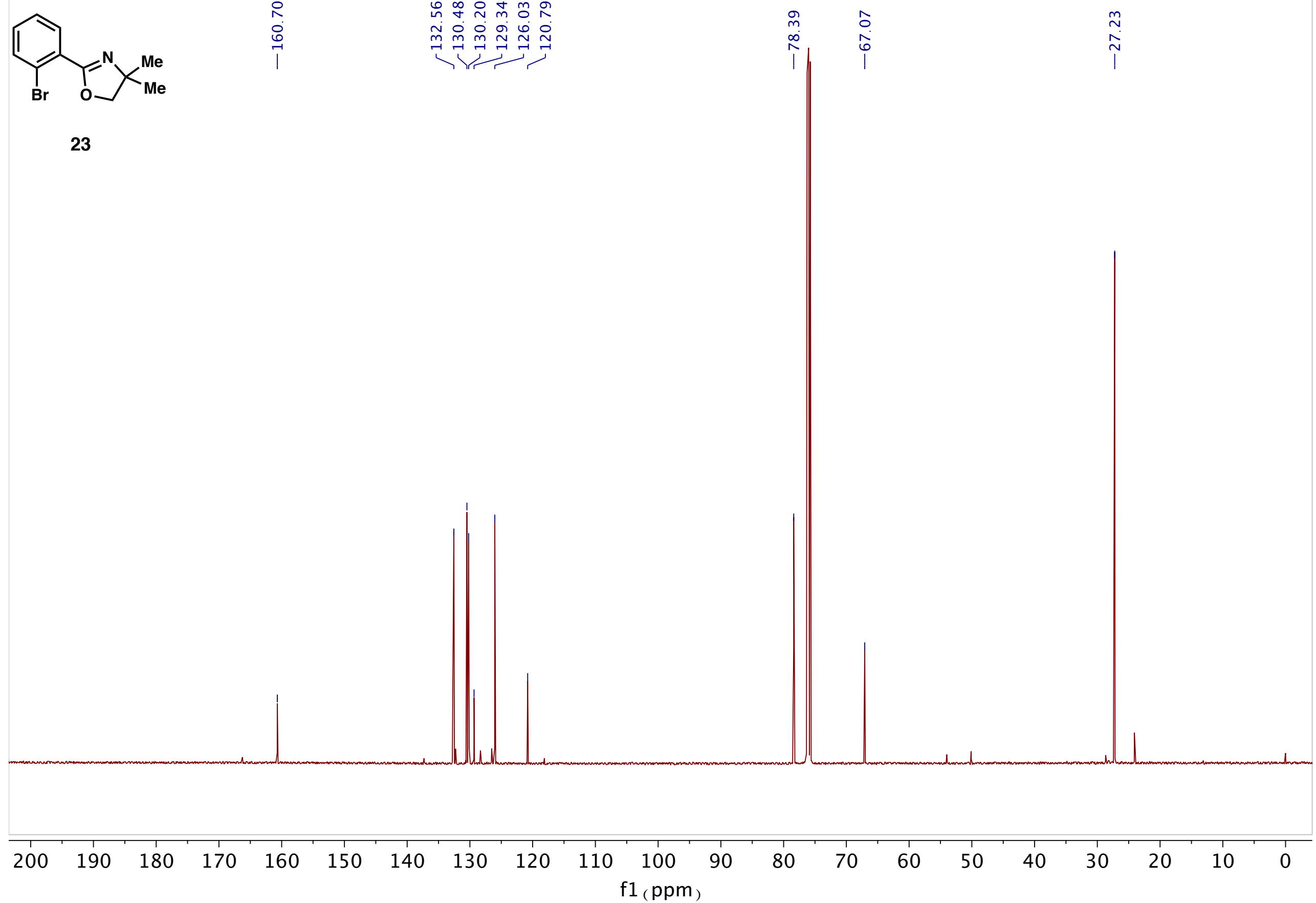


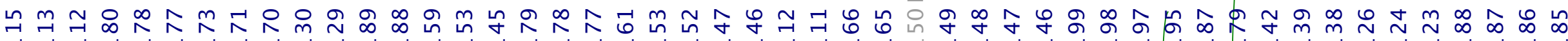

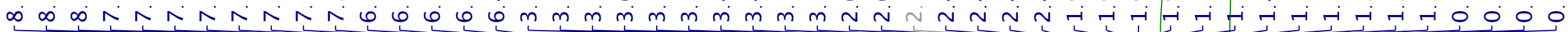
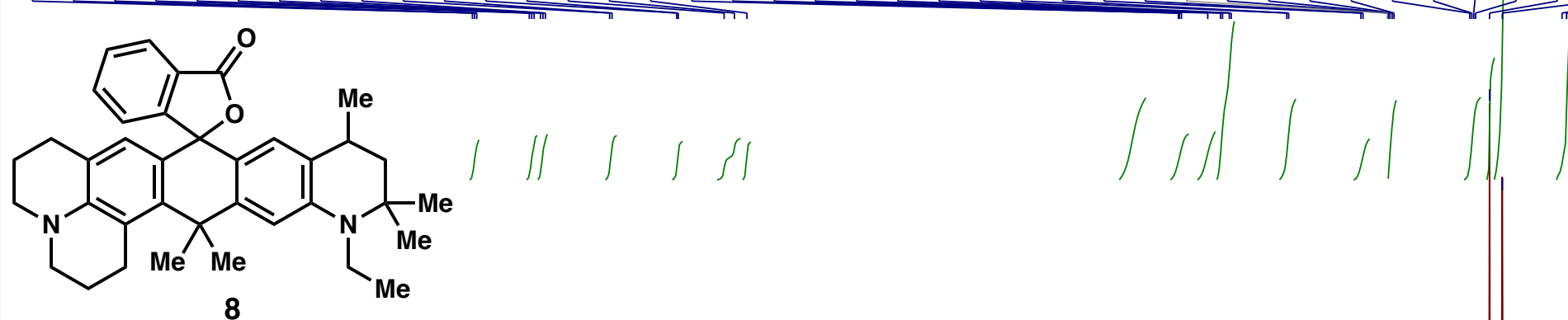

$$
\text { - }
$$


${ }^{13} \mathrm{C}$ NMR, DMSO- $d_{6}, 126 \mathrm{MHz}$
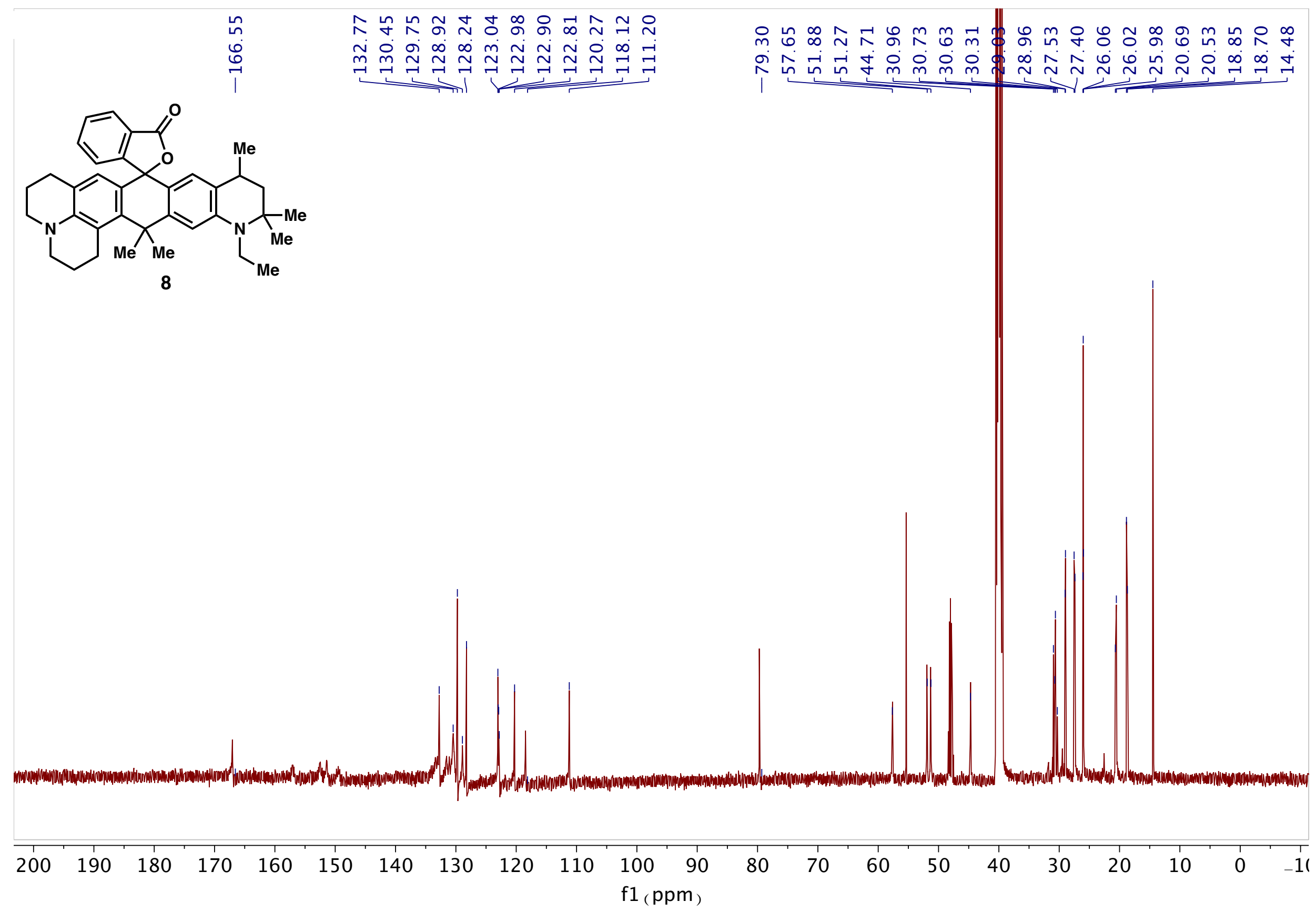


\section{品}

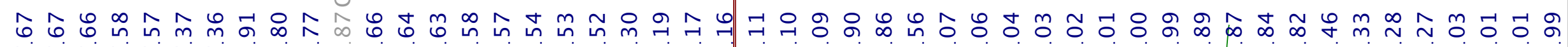

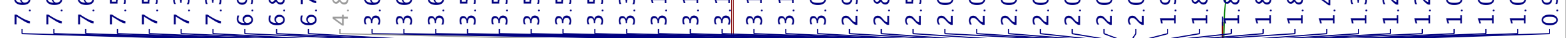
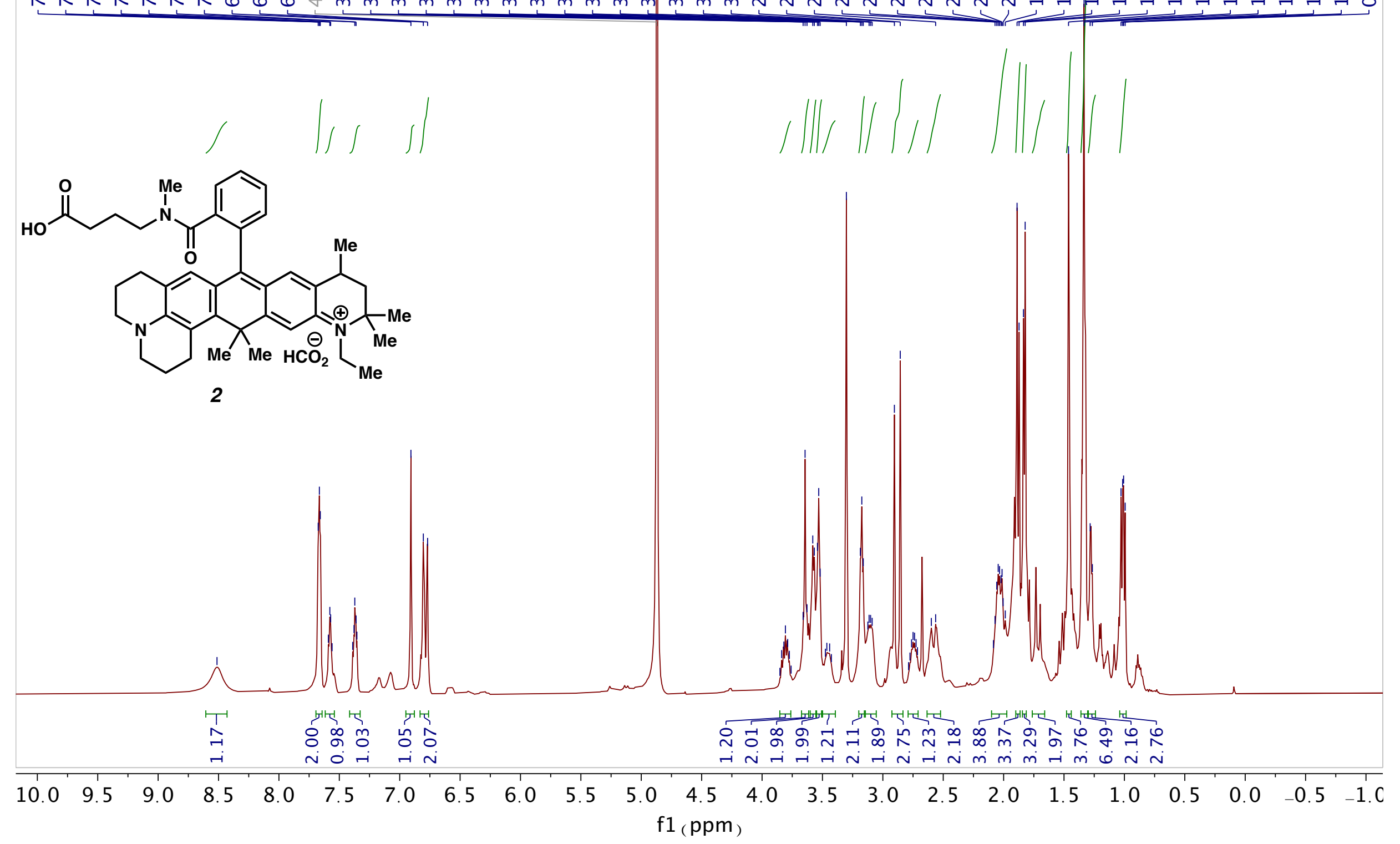
${ }^{13} \mathrm{C}$ NMR, $\mathrm{CD}_{3} \mathrm{OD}, 126 \mathrm{MHz}$

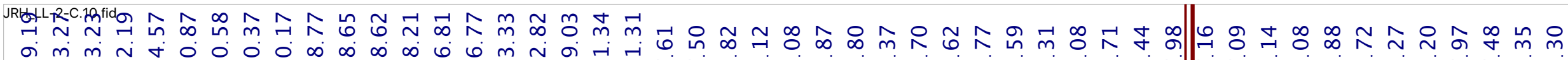

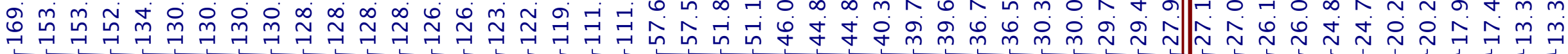

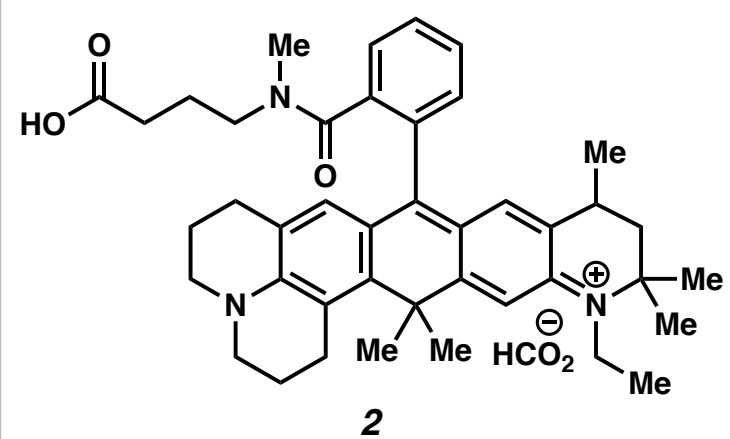

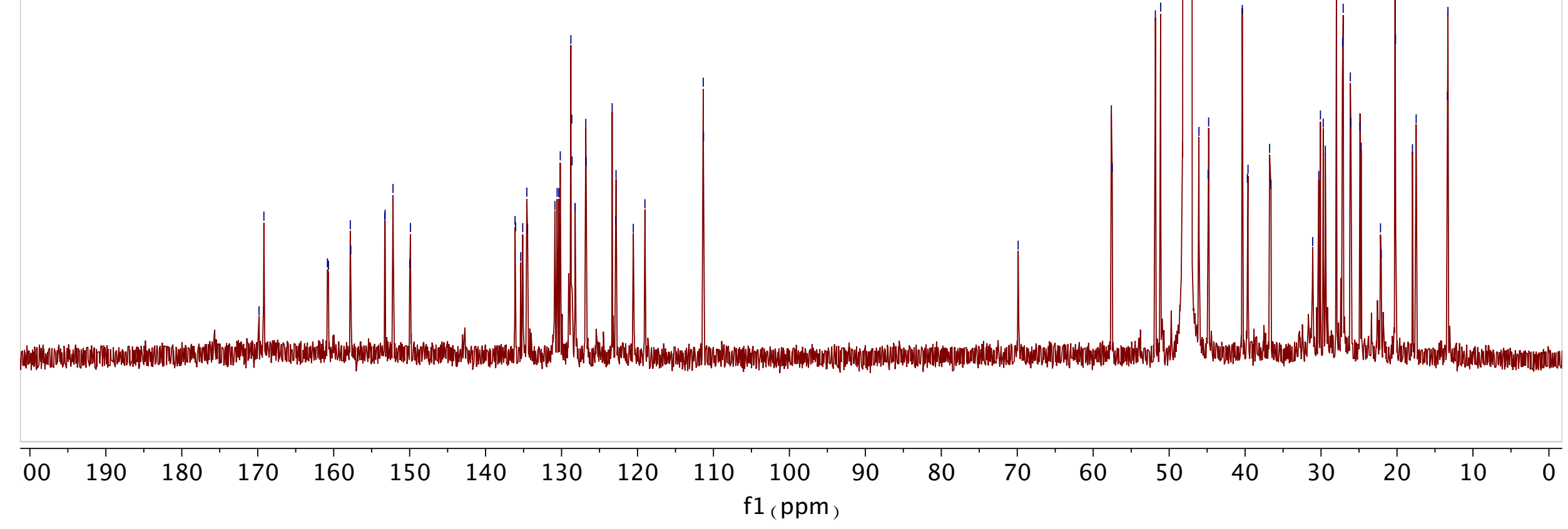


Target Compound Screening Report

Results Acquired by The University of Texas at Austin Mass Spectrometry Facility

\begin{tabular}{llllll}
$\begin{array}{l}\text { Data File } \\
\text { Position }\end{array}$ MSF19-0102(JLB_5_attopaper_8)_hrESIpos2.d & Sample Name & 0102(JLB_5_attopaper_8) & Comment & 0102(JLB_5_attopaper_8) \\
Acq Method & pos.m & Instrument Name & Instrument 1 & Aser Name \\
& & Acquired Time & $1 / 28 / 201911: 48: 50$ AM & DA Method KS.m & \\
\hline
\end{tabular}

MS Zoomed Spectrum

x10 5 Cpd 1: C13 H17 N O: +ESI Scan (0.19-0.23 min, 3 Scans) Frag=180.0V MSF19-0102(JLB_5_attopap...

204.1387

3-

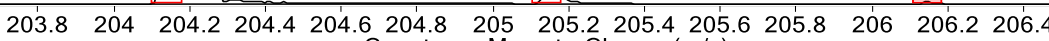

205.1417

N

206.1452

Counts vs. Mass-to-Charge $(\mathrm{m} / \mathrm{z})$

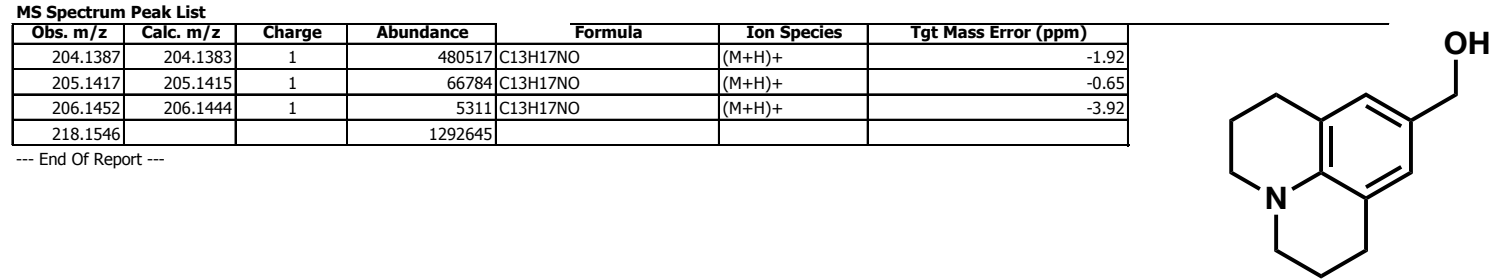

10

Agilent Technologies

Page 1 of 1

Printed at: 11:50 AM on:1/28/2019 
Target Compound Screening Report

Results Acquired by The University of Texas at Austin Mass Spectrometry Facility

\begin{tabular}{llllll} 
Data File & MSF19-0100(JLB_5_attopaper_3)_hrESIpos1.d & Sample Name & 0100(JLB_5_attopaper_3) & Comment \\
$\begin{array}{l}\text { Position } \\
\text { Acq Method }\end{array}$ & pos.m & Instrument Name & Instrument 1 & User Name & Acattopaper_3) \\
& & Acquired Time & $1 / 28 / 201911: 40: 04$ AM & DA Method & KS.m \\
\hline
\end{tabular}

MS Zoomed Spectrum

x10 6 Cpd 1: C14 H18 Br N: +ESI Scan (0.20-0.23 min, 3 Scans) Frag=180.0V MSF19-0100(JLB_5_attopa...

6 - 280.0700

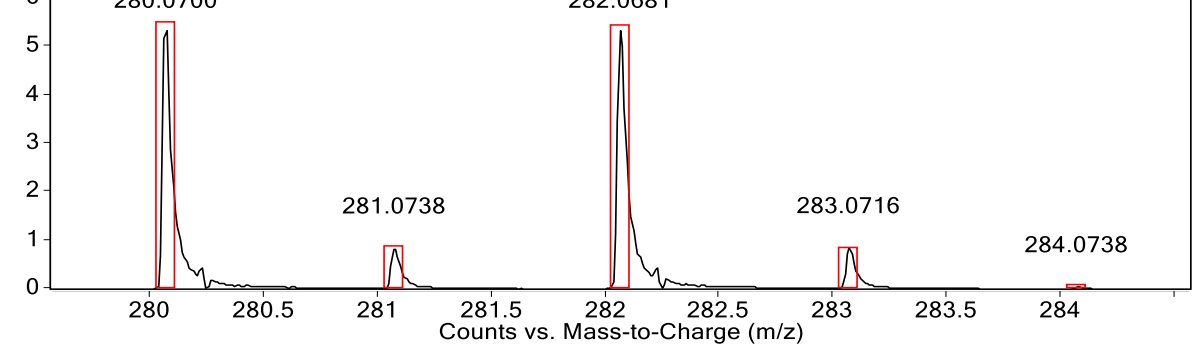

MS Spectrum Peak List

\begin{tabular}{|c|c|c|c|c|c|c|c|}
\hline Obs. $\mathbf{m} / \mathbf{z}$ & Calc. $\mathbf{m} / \mathbf{z}$ & Charge & Abundance & Formula & Ion Species & Tgt Mass Error (ppm) & \\
\hline 280.0700 & 280.0695 & 1 & 5436155 & C14H18BrN & $(\mathrm{M}+\mathrm{H})+$ & -1.66 & Me \\
\hline 281.0738 & 281.0728 & 1 & 858218 & C14H18BrN & $(\mathrm{M}+\mathrm{H})+$ & -3.44 & \\
\hline 282.0681 & 282.0676 & 1 & 5476293 & C14H18BrN & $(\mathrm{M}+\mathrm{H})+$ & -1.69 & \\
\hline 283.0716 & 283.0708 & 1 & 864823 & C14H18BrN & $(\mathrm{M}+\mathrm{H})+$ & -3.02 & \\
\hline 284.0738 & 284.0740 & 1 & 57346 & $\begin{array}{l}\mathrm{C} 14 \mathrm{H} 18 \mathrm{BrN} \\
\end{array}$ & $(\mathrm{M}+\mathrm{H})+$ & 0.65 & \\
\hline 285.0733 & 285.0772 & 1 & 3858 & C14H18BrN & $(\mathrm{M}+\mathrm{H})+$ & 13.88 & \\
\hline
\end{tabular}

12 
Target Compound Screening Report

Results Acquired by The University of Texas at Austin Mass Spectrometry Facility

\begin{tabular}{llllll} 
Data File & MSF19-0220(JLB_5_attopaper_4)_hrESIpos2.d & Sample Name & 0220(JLB_5_attopaper_4) & Comment & 0220(JLB_5_attopaper_4) \\
Position & P1-E8 & Instrument Name & Instrument 1 & User Name \\
Acq Method & pos.m & Acquired Time & $1 / 30 / 20191: 40: 44$ PM & DA Method & KS.m \\
& & & & \\
\hline
\end{tabular}

MS Zoomed Spectrum

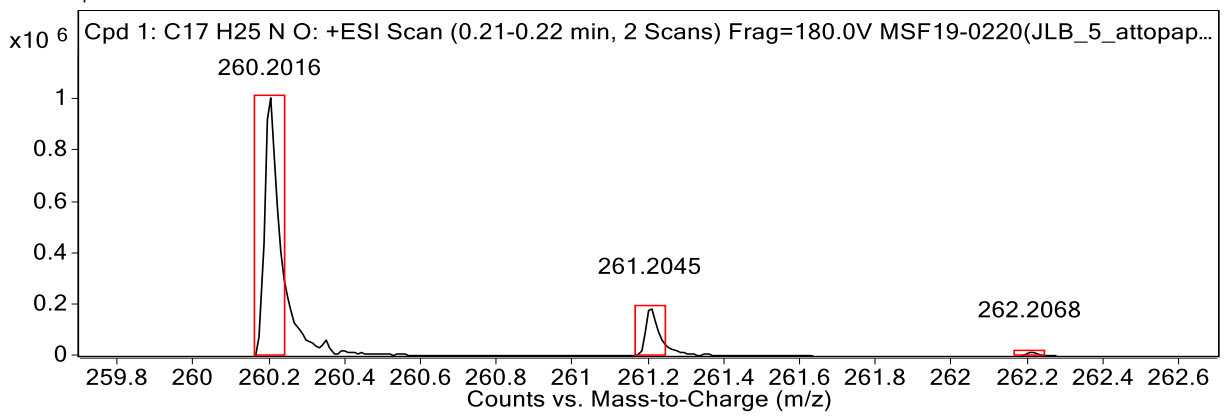

MS Spectrum Peak List

MS Spectrum Peak List
\begin{tabular}{|r|r|c|r|r|r|r|r|}
\hline Obs. m/z & Calc. m/z & Charge & \multicolumn{1}{c|}{ Abundance } & Formula & Ion Species & Tgt Mass Error (ppm) \\
\hline 260.2016 & 260.2009 & 1 & 1016109 & $\mathrm{C} 17 \mathrm{H} 25 \mathrm{NO}$ & $\mathrm{M}+\mathrm{H})+$ & -2.88 \\
\hline 261.2045 & 261.2042 & 1 & 189438 & $\mathrm{C} 17 \mathrm{H} 25 \mathrm{NO}$ & $\mathrm{(M+H)+}$ & 1.07 \\
\hline 262.2068 & 262.2072 & 1 & 19743 & $\mathrm{C} 17 \mathrm{H} 25 \mathrm{NO}$ & $(\mathrm{M}+\mathrm{H})+$ & 9.66 \\
\hline 263.2075 & 263.2101 & 1 & 1673 & $\mathrm{C} 17 \mathrm{H} 25 \mathrm{NO}$ & $(\mathrm{M}+\mathrm{H})+$ & \\
\hline-- End Of Report ---
\end{tabular}


Target Compound Screening Report

Results Acquired by The University of Texas at Austin Mass Spectrometry Facility

$\begin{array}{llllll}\text { Data File } & \text { MSF19-0221(JLB_5_attopaper_5)_hrESIpos1.d } & \text { Sample Name } & \text { 0221(JLB_5_attopaper_5) } & \text { Comment } & \text { 0221(JLB_5_attopaper_5) } \\ \text { Position } & \text { P1-E9 } & \text { Instrument Name } & \text { Instrument 1 } & \text { User Name } \\ \text { Acq Method } & \text { pos.m } & \text { Acquired Time } & 1 / 30 / 20191: 42: 40 \text { PM } & \text { DA Method } & \text { KS.m }\end{array}$

MS Zoomed Spectrum

x10 5 Cpd 1: C17 H27 N O: +ESI Scan (0.20-0.22 min, 2 Scans) Frag=180.0V MSF19-0221(JLB_5_attopap..

3 . 262.2168

2.5

2

1.5

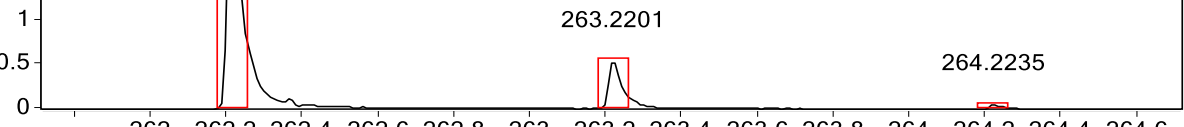

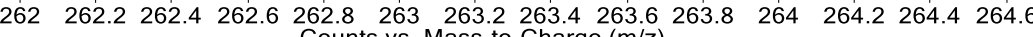
Counts vs. Mass-to-Charge $(\mathrm{m} / \mathrm{z})$

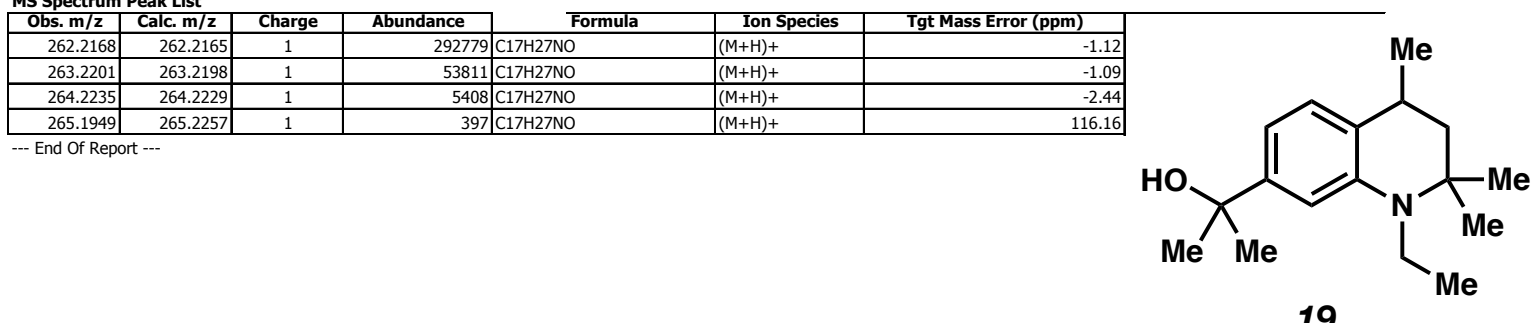

19 
Target Compound Screening Report

Results Acquired by The University of Texas at Austin Mass Spectrometry Facility

\begin{tabular}{|c|c|c|c|c|c|}
\hline Data File & MSF19-0101(JLB_5_attopaper_6)_hrESIpos1.d & Sample Name & 0101(JLB_5_attopaper_6) & Comment & 0101(JLB_5_attopaper_6) \\
\hline Position & P1-B9 & Instrument Name & Instrument 1 & User Name & \\
\hline Acq Method & pos.m & Acquired Time & 1/28/2019 11:42:25 AM & DA Method & $\mathrm{KS} . \mathrm{m}$ \\
\hline
\end{tabular}

MS Zoomed Spectrum

x10 6 Cpd 1: C17 H25 N: +ESI Scan (0.19-0.23 min, 3 Scans) Frag=180.0V MSF19-0101(JLB_5_attopaper...

244.2065

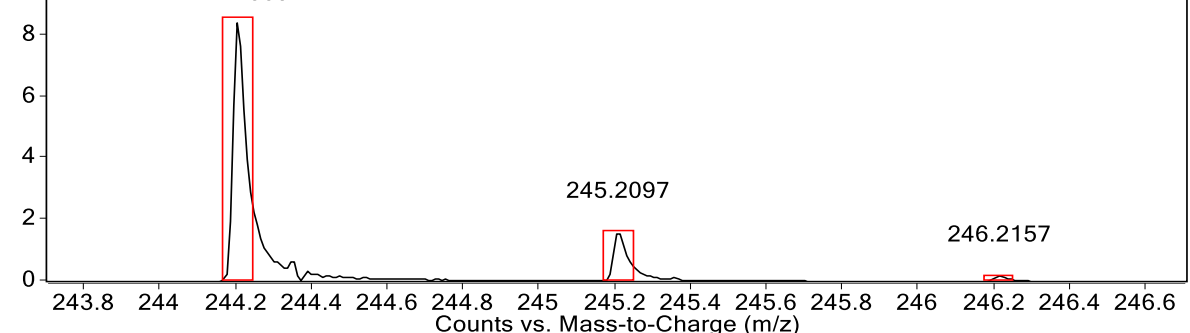

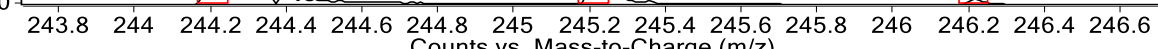

Counts vs. Mass-to-Charge $(\mathrm{m} / \mathrm{z})$

MS Spectrum Peak List
\begin{tabular}{|r|r|c|r|l|l|r|r|}
\hline Obs. m/z & Calc. m/z & Charge & \multicolumn{1}{c|}{ Abundance } & Formula & Ion Species & Tgt Mass Error (ppm) \\
\hline 244.2065 & 244.2060 & 1 & 8533553 & $\mathrm{C} 17 \mathrm{H} 25 \mathrm{~N}$ & $(\mathrm{M}+\mathrm{H})+$ & -1.95 \\
\hline 245.2097 & 245.2093 & 1 & 1610931 & $\mathrm{C} 17 \mathrm{H} 25 \mathrm{~N}$ & $(\mathrm{M}+\mathrm{H})+$ & -12.84 \\
\hline 246.2157 & 246.2125 & 1 & 191540 & $\mathrm{C} 17 \mathrm{H} 25 \mathrm{~N}$ & $(\mathrm{M}+\mathrm{H})+$ & -22.56 \\
\hline 247.2214 & 247.2158 & 1 & 15588 & $\mathrm{C} 17 \mathrm{H} 25 \mathrm{~N}$ & $(\mathrm{M}+\mathrm{H})+$ &
\end{tabular}

11 
Target Compound Screening Report

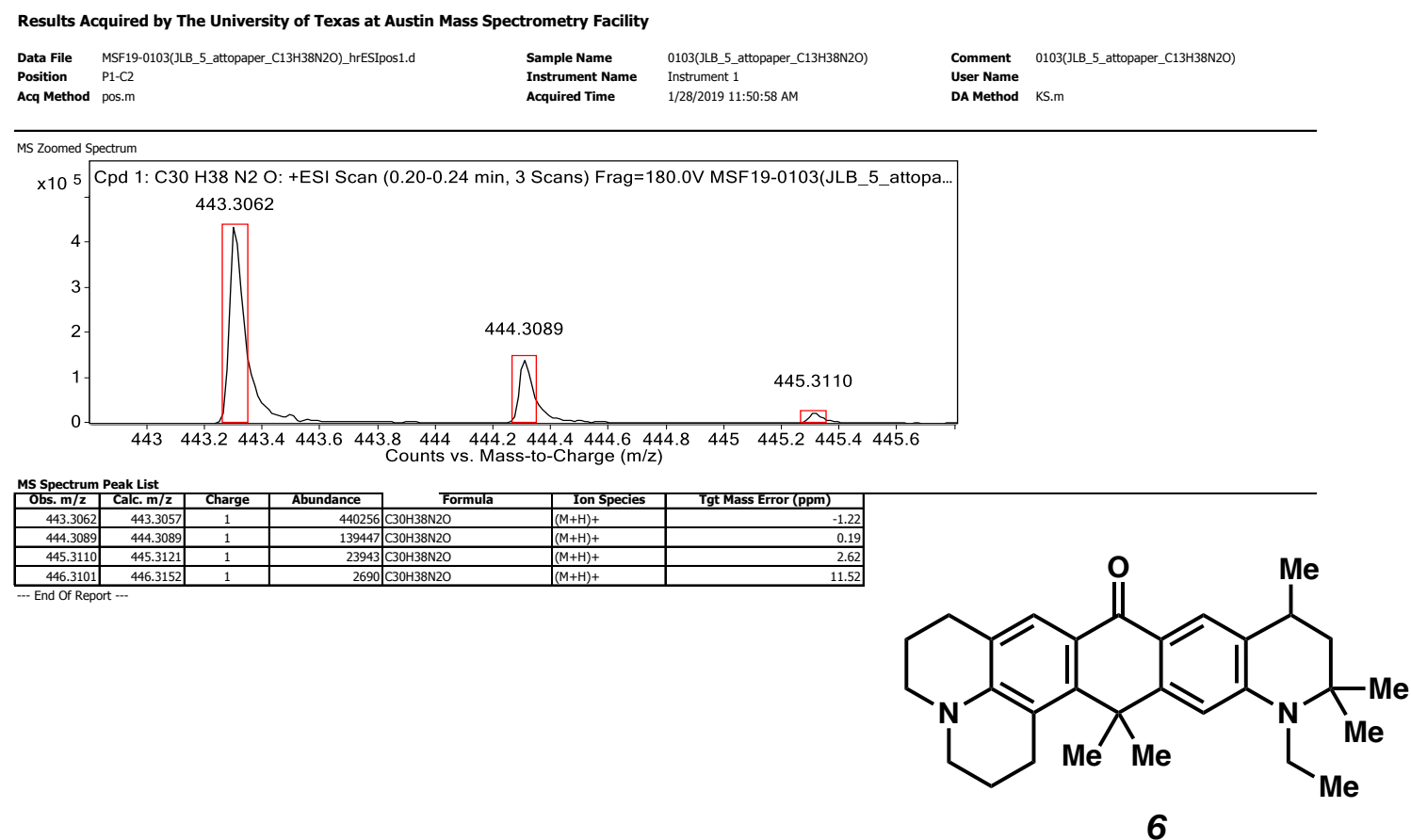


Target Compound Screening Report

Results Acquired by The University of Texas at Austin Mass Spectrometry Facility

\begin{tabular}{|c|c|c|c|c|c|}
\hline Data File & MSF19-0104(JLB_5_attopaper_10)_hrESIpos1.d & Sample Name & 0104(JLB_5_attopaper_10) & Comment & 0104(JLB_5_attopaper_10) \\
\hline Position & P1-C3 & Instrument Name & Instrument 1 & User Name & \\
\hline Acq Method & pos.m & Acquired Time & 1/28/2019 11:52:23 AM & DA Method & KS.m \\
\hline
\end{tabular}

Acq Method pos.m

1/28/2019 11:52:23 AM

DA Method KS.m

MS Zoomed Spectrum

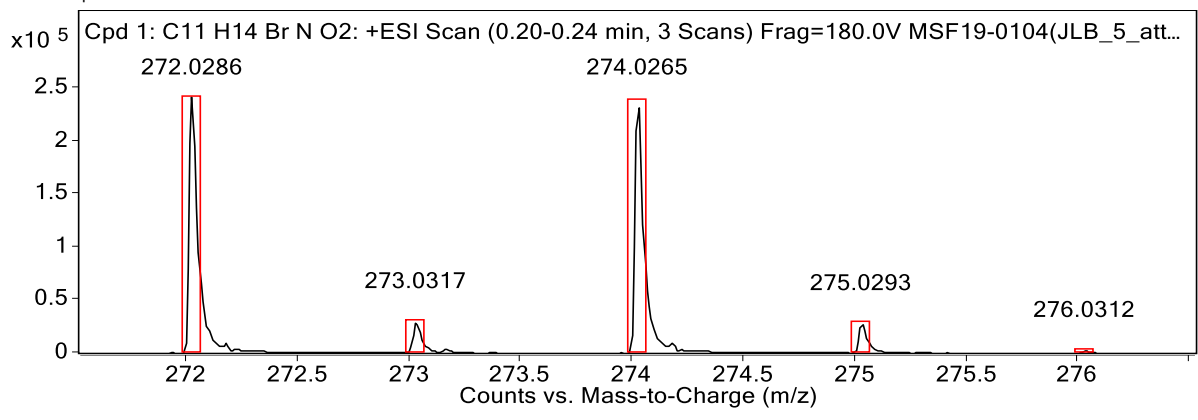

\begin{tabular}{|c|c|c|c|c|c|c|}
\hline Obs. $\mathbf{m} / \mathbf{z}$ & Calc. $\mathbf{m} / \mathbf{z}$ & Charge & Abundance & Formula & Ion Species & Tgt Mass Error (ppm) \\
\hline 272.0286 & 272.0281 & 1 & 241475 & C11H14BrNO2 & $(M+H)+$ & -1.93 \\
\hline 273.0317 & 273.0313 & 1 & 29705 & C11H14BrNO2 & $(\mathrm{M}+\mathrm{H})+$ & -1.43 \\
\hline 274.0265 & 274.0261 & 1 & 233340 & C11H14BrNO2 & $(M+H)+$ & -1.59 \\
\hline 275.0293 & 275.0293 & 1 & 27798 & C11H14BrNO2 & $(\mathrm{M}+\mathrm{H})+$ & -0.02 \\
\hline 276.0312 & 276.0317 & 1 & 2510 & C11H14BrNO2 & $(M+H)+$ & 1.67 \\
\hline 277.0225 & 277.0342 & 1 & 334 & $\mathrm{C} 11 \mathrm{H} 14 \mathrm{BrNO} 2$ & $(\mathrm{M}+\mathrm{H})+$ & 42.05 \\
\hline 296.0086 & & & 355360 & & & \\
\hline
\end{tabular}

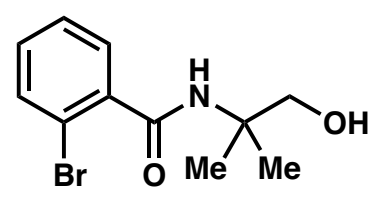

22 
Target Compound Screening Report

Results Acquired by The University of Texas at Austin Mass Spectrometry Facility

$\begin{array}{llllll}\text { Data File } & \text { MSF19-0105(JLB_5_attopaper_11)_hrESIpos1.d } & \text { Sample Name } & \text { 0105(JLB_5_attopaper_11) } & \text { Comment } & \text { 0105(JLB_5_attopaper_11) } \\ \text { Position } & \text { P1-C4 } & \text { Instrument Name } & \text { Instrument 1 } & \text { User Name } & \text { DA Method } \\ \text { Acq Method.m } & \text { pos.m } & \text { Acquired Time } & 1 / 28 / 201911: 57: 32 \text { AM } & \text { DA } & \end{array}$

MS Zoomed Spectrum

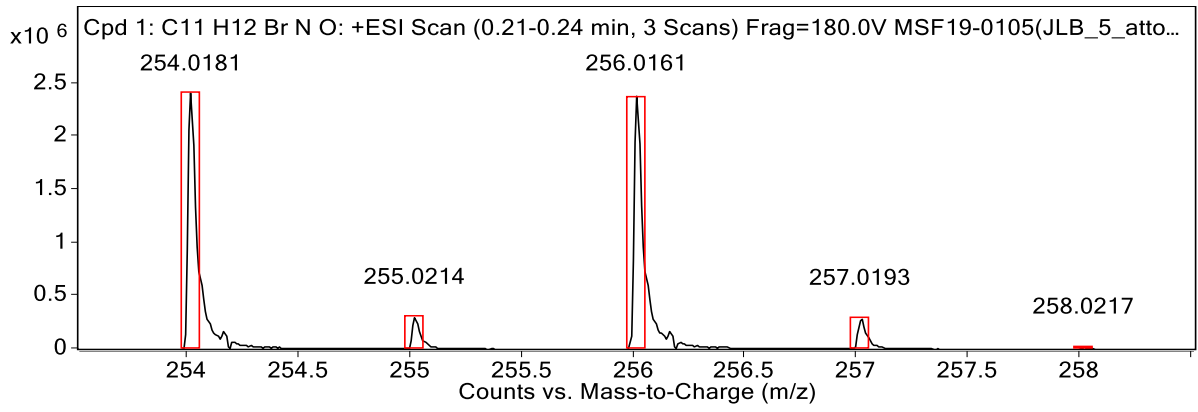

MS Spectrum Peak List

MS Spectrum Peak List
\begin{tabular}{|r|r|c|r|r|r|r|}
\hline Obs. m/z & Calc. m/z & Charge & Abundance & \multicolumn{1}{c|}{ Formula } & Ion Species & Tgt Mass Error (ppm) \\
\hline 254.0181 & 254.0175 & 1 & 2412240 & $\mathrm{C} 11 \mathrm{H} 12 \mathrm{BrNO}$ & $(\mathrm{M}+\mathrm{H})+$ & -2.18 \\
\hline 255.0214 & 255.0207 & 1 & 298567 & $\mathrm{C} 11 \mathrm{H} 12 \mathrm{BrNO}$ & $(\mathrm{M}+\mathrm{H})+$ & -2.51 \\
\hline 256.0161 & 256.0155 & 1 & 2372977 & $\mathrm{C} 11 \mathrm{H} 12 \mathrm{BrNO}$ & $(\mathrm{M}+\mathrm{H})+$ & -2.16 \\
\hline 257.0193 & 257.0187 & 1 & 289412 & $\mathrm{C} 11 \mathrm{H} 12 \mathrm{BrNO}$ & $(\mathrm{M}+\mathrm{H})+$ & -1.24 \\
\hline 258.0217 & 258.0214 & 1 & 19057 & $\mathrm{C} 11 \mathrm{H} 12 \mathrm{BrNO}$ & $(\mathrm{M}+\mathrm{H})+$ & -1.75 \\
\hline 259.0244 & 259.0240 & 1 & $1315 \mathrm{C} 11 \mathrm{H} 12 \mathrm{BrNO}$ & $(\mathrm{M}+\mathrm{H})+$ &
\end{tabular}

23 
Target Compound Screening Report

Results Acquired by The University of Texas at Austin Mass Spectrometry Facility

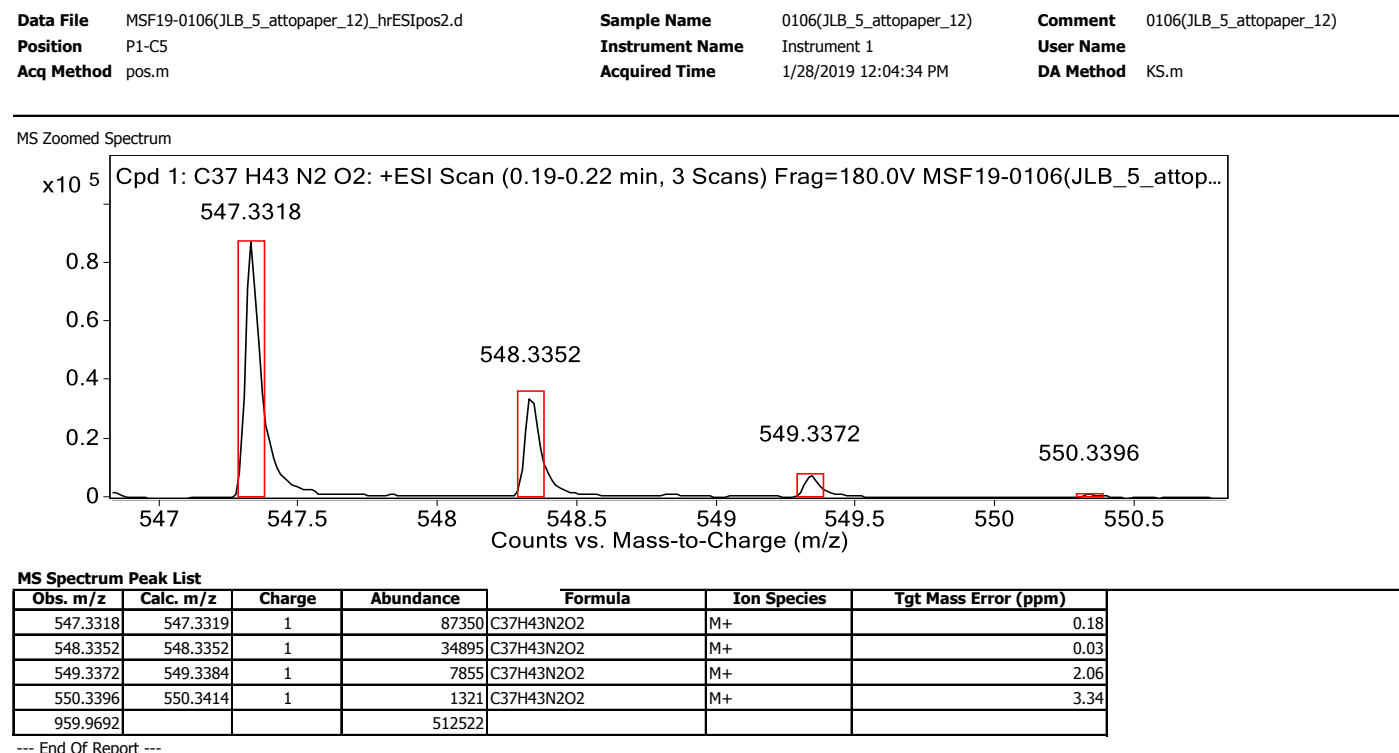

--- End Of Report ---

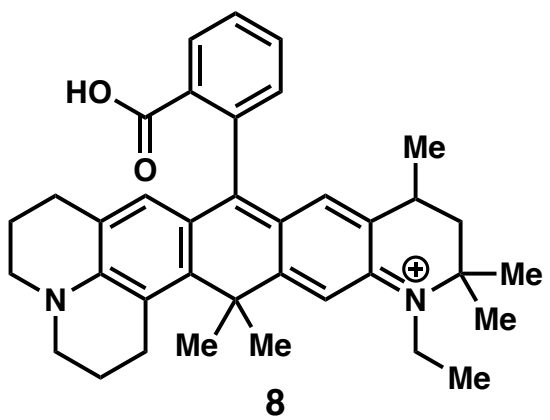


$\mathrm{ESI}^{+}$LCMS trace (UV $280 \mathrm{~nm}$ ):

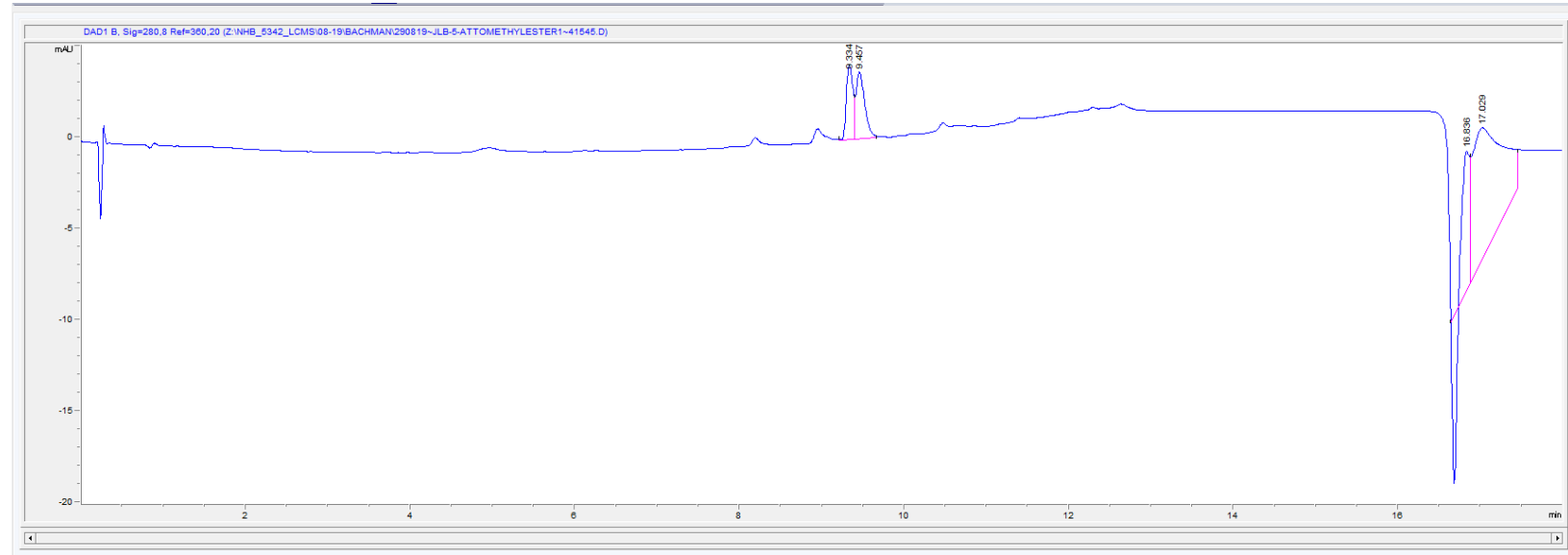

$\mathrm{m} / \mathrm{z}$ corresponding to peaks at 9.33 and 9.457 - both atropisomers of the methyl ester

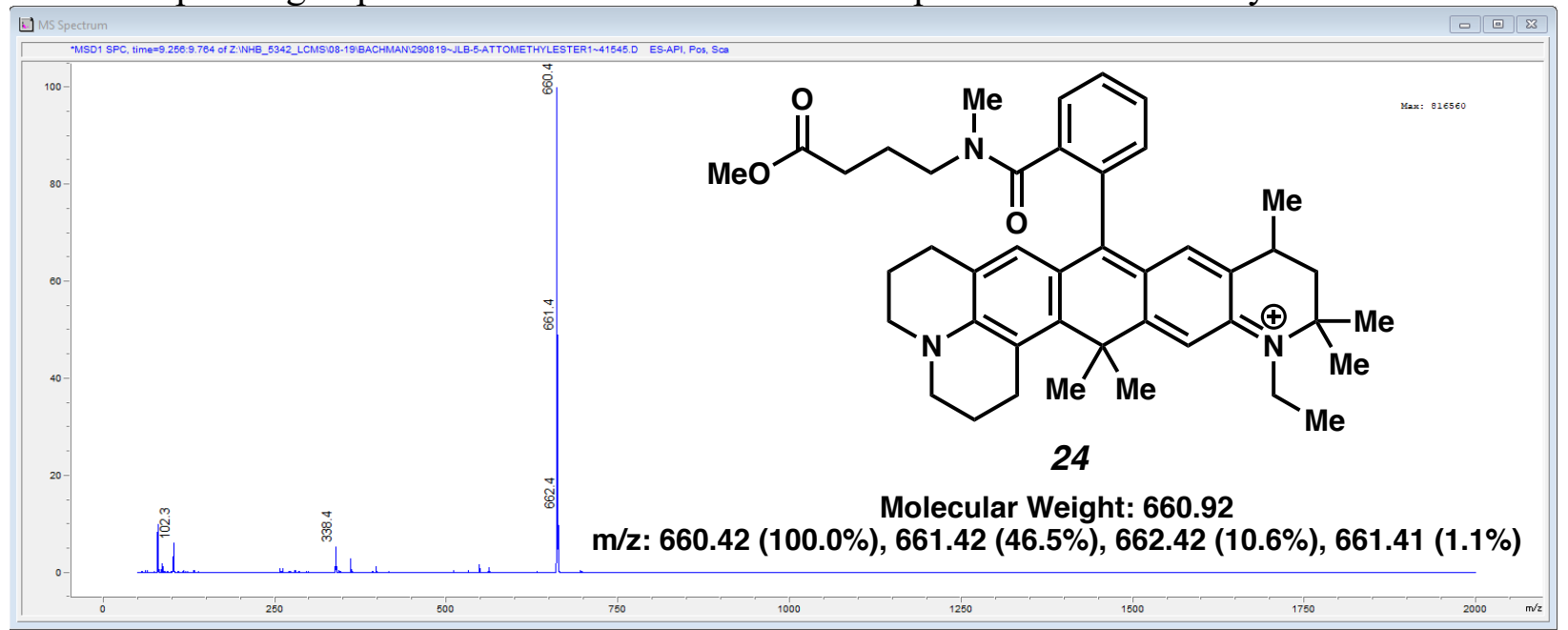


Target Compound Screening Report

Results Acquired by The University of Texas at Austin Mass Spectrometry Facility

$\begin{array}{llllll}\text { Data File } & \text { MSF19-1679(JLB-5-carboxy-647N)_hrESIpos1.d } & \text { Sample Name } & \text { 1679(JLB-5-carboxy-647N) } & \text { Comment } & \text { 1679(JLB-5-carboxy-647N) } \\ \text { Position } & \text { P1-B1 } & \text { Instrument Name } & \text { Instrument } 1 & \text { User Name } & \\ \text { Acq Method } & \text { FIA_pos.m } & \text { Acquired Time } & 8 / 30 / 201912: 50: 33 \text { PM } & \text { DA Method } & \text { KS.m }\end{array}$

MS Zoomed Spectrum

x10 5 Cpd 1: C42 H52 N3 O3: +ESI Scan (0.20-0.21 min, 2 Scans) Frag=180.0V MSF19-1679(JLB-5-carbo...

646.4006

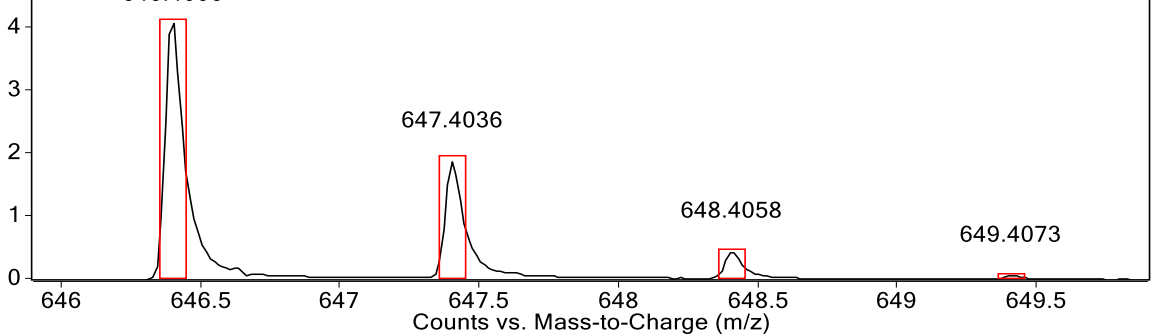

MS Spectrum Peak List

\begin{tabular}{|c|c|c|c|c|c|c|}
\hline Obs. $m / z$ & Calc. $m / z$ & Charge & Abundance & Formula & Ion Species & Tgt Mass Error (ppm) \\
\hline 646.4006 & 646.4003 & 1 & 412461 & $\mathrm{C} 42 \mathrm{H} 52 \mathrm{~N} 3 \mathrm{O} 3$ & $\mathrm{M}+$ & -0.49 \\
\hline 647.4036 & 647.4036 & 1 & 188959 & C42H52N3O3 & $\mathrm{M}+$ & -0.04 \\
\hline 648.4058 & 648.4067 & 1 & 45184 & $\mathrm{C} 42 \mathrm{H} 52 \mathrm{~N} 3 \mathrm{O} 3$ & $\mathrm{M}+$ & 1.42 \\
\hline 649.4073 & 649.4097 & 1 & 6847 & $\mathrm{C} 42 \mathrm{H} 52 \mathrm{~N} 3 \mathrm{O} 3$ & $\mathrm{M}+$ & 3.69 \\
\hline 650.4089 & 650.4127 & 1 & 1054 & C42H52N3O3 & $\mathrm{M}+$ & 5.76 \\
\hline
\end{tabular}

-- End Of Report ---

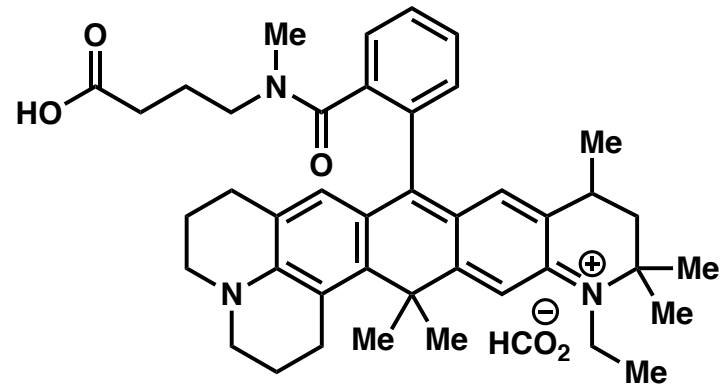




\section{References:}

1. Cai, G.; Bozhkova, N.; Odingo, J.; Berova, N.; Nakanishi, K., Circular dichroism exciton chirality method. New red-shifted chromophores for hydroxyl groups. J. Am. Chem. Soc. 1993, 115 (16), 7192-7198.

2. Koide, Y.; Urano, Y.; Hanaoka, K.; Piao, W.; Kusakabe, M.; Saito, N.; Terai, T.; Okabe, T.; Nagano, T., Development of NIR Fluorescent Dyes Based on Si-rhodamine for in Vivo Imaging. J. Am. Chem. Soc. 2012, 134 (11), 5029-5031.

3. Meerwein, H., Triethyloxonium Fluoborate. Organic Syntheses 1966, 46, 113.

4. Meyers, A. I.; Temple, D. L., Syntheses via 2-oxazolines. III. Formation of substituted benzoic acids or esters utilizing the Grignard reagent of 2-(bromophenyl)-2-oxazolines. J. Am. Chem. Soc. 1970, 92 (22), 6646-6647. 